\title{
Kamu Teşvik Mekanizmalarının Yenilenebilir Enerji Kaynakları Üzerine Etkisi: AB Ülkeleri ve Türkiye'de Güneş Enerjisine Yönelik Dinamik Panel Veri Analizi ${ }^{1}$
}

\author{
Halil İbrahim KAYA (https://orcid.org/0000-0001-8331-0853), Department of Economics, Sivas Cumhuriyet \\ University, Turkey; e-mail: hkaya.cum@gmail.com
}

Yüksel BAYRAKTAR (https://orcid.org/0000-0002-3499-4571), Department of Economics, Istanbul University, Turkey; e-mail: ybayraktar@istanbul.edu.tr

\section{The Effects of Public Incentive Mechanisms on the Renewable Energy Resources: Dynamic Panel Data Analysis for Solar Energy Capacity in the EU Countries and Turkey ${ }^{2}$}

\begin{abstract}
Renewable energy investments have increased substantially throughout the World due to the limitation of fossil fuels, the energy supply security, the increasing environmental awareness, and the concerns over sustainable and clean energy consumption. The long-term and costly return of renewable energy investments has led governments to develop incentive mechanisms with medium and long-term plans. Notwithstanding, limited public resources necessitate determining the optimal incentive mechanism for policymakers to design effective investment plans in the renewable energy sector. Thus, the purpose of this study is to reveal the effects of incentive mechanisms on renewable energy investments and determine the optimal incentive mechanism. The relationship between the incentive instruments and the installed solar energy power capacity is analysed in the study. Analyses are carried out with the dynamic panel data method based on single-stage and two-stage Arellano-Bond Generalized Moments Methods for 28 countries with annual data belonging to the period between 2001 and 2015. The findings indicate that while feed-in tariff/feed-in premium, tax incentives, green certificate system, and GDP positively correlate with installed solar energy capacity, energy import negatively correlates with the installed solar energy capacity. Subsidies and loans show no correlation with the installed solar energy capacity.
\end{abstract}

Keywords

Public Incentive Mechanisms, Renewable Energy, Solar Energy, EU Countries, Turkey, Dynamic Panel Data Analysis.

JEL Classification Codes : $\quad$ C33, Q4, Q42.

\section{$\ddot{\mathbf{O} z}$}

Fosil yakıtların sınırlılığı, enerji arz güvenliği, yükselen çevre bilinci, enerji tüketiminin sürdürülebilir ve temiz olması kaygıları dünya genelinde alternatif bir enerji kaynağı olarak yenilenebilir enerji yatırımlarını artırmıştır. Yenilebilir enerji yatırımlarının maliyetli ve geri

I Bu çalışma İstanbul Üniversitesi Sosyal Bilimler Enstitüsü’ne sunulan “Teşvik Mekanizmalarının Yenilenebilir Enerji Yatırımları Üzerine Etkisi: AB Ülkeleri ve Türkiye'de Güneş Enerjisi Yatırımlarına Yönelik Ampirik Bir Çalışma" başlıklı doktora tezinden türetilmişstir.

2 This study was derived from Ph.D. dissertation "Effect of Incentive Mechanisms on the Renewable Energy Investments: A Research on EU Countries and Turkey's Solar Energy Investment" which was accepted in the Institute of Social Sciences, Istanbul University. 
Kaya, H.İ. \& Y. Bayraktar (2021), "Kamu Teşvik Mekanizmalarının Yenilenebilir Enerji Kaynakları Üzerine Etkisi: AB Ülkeleri ve Türkiye'de Güneş Enerjisine Yönelik Dinamik Panel Veri Analizi”, Sosyoekonomi, 29(48), 181-204.

dönüşünün uzun dönemli olması, bu alana ilgiyi artırmak isteyen hükümetleri orta ve uzun vadeli planlarla teşvik mekanizmaları geliştirmeye yöneltmiştir. Teşviklerin sınırsız olmayan kamu kaynaklarından finanse edilmesi, optimal teşvik mekanizmasının tespit edilerek politika yapıcıya yol göstermesi açısından önemlidir. Bu çalışmanın amacı, teşvik mekanizmalarının yenilenebilir enerji yatırımlarını ne ölçüde etkilediğini ortaya koymak ve optimal teşvik mekanizmalarını belirlemektir. Çalışmada, teşvik araçları ile güneş enerjisi kurulu güç kapasitesi arasındaki ilişki, 2001-2015 arası yıllık verileriyle 28 ülke için tek aşamalı ve iki aşamalı Arellano Bond Genelleştirilmiş Momentler Metoduna dayalı dinamik panel yöntemiyle incelenmiştir. Çalışmanın bulguları, tarife garantisi/prim sisteminin, vergi teşviklerinin, yeşil sertifika sisteminin ve GSYİH'nin, güneş enerjisi kurulu güç kapasite artışı ile pozitif ve anlamlı ilişkili olduğu, enerji ithalatı ve güneş enerjisi kurulu güç kapasitesi artışı arasında negatif ve anlamlı ilişki olduğu, sübvansiyonlar ve krediler ile güneş enerjisi kurulu gücü artışı arasında anlamlı bir ilişki olmadığı yönündedir.

Anahtar Sözcükler $\quad$ : Kamu Teşvik Mekanizmaları, Yenilenebilir Enerji, Güneş Enerjisi, AB Ülkeleri, Türkiye, Dinamik Panel Veri Analizi.

\section{Giriş}

Fosil yakıtların sınırlı olması, her ülkede yeterince bulunamaması ve aşırı tüketiminin küresel 1sınmayı artırması gibi nedenler, hükümetlerin yeşil enerji programları, ulusal enerji programları gibi politikalar ile yenilenebilir enerji yatırımları için yol haritası belirlemesine neden olmuştur. Enerji arz güvenliği yaşayan ve fosil yakıtlara bağımlı olan ülkeler açısından yenilenebilir enerji, önemli bir alternatif enerji kaynağı haline gelmiştir. Yenilenebilir enerji özellikle AB ülkeleri, ABD, Çin, Japonya ve Hindistan gibi ülkelerin yüksek miktarlarda yatırımlar yaptığı bir alan olarak göze çarpmaktadır. Enerji sektörü içerisinde yatırımcıları yenilenebilir enerji yatırımına yöneltecek teşviklerin ve düzenlemelerin yapılması, önlemlerin alınması hükümetlerin enerji politikalarında ayrıcalıklı ve öncelikli bir konu olmuştur. Yenilenebilir enerji kaynaklarından daha çok faydalanabilmek isteyen hükümetler, orta ve uzun vadeli kalkınma planları içerisinde yenilenebilir enerjinin kullanımını artırmaya yönelik hedefler belirlemiş ve bu hedeflere ulaşabilmek için çeşitli teşvik araçları geliştirerek, yatırımcıları ilgili alana çekmeyi amaçlamıştır. Hükümetler tarafından izlenen politikalar, özel yatırımcının finansmanının sağlanmasında ve uzun dönemli yatırım riskinin azaltılmasında merkezi bir rol oynamaktadır. Bu nedenle hükümetler, en etkin teşvik mekanizmasını ve politikasını hayata geçirmelidir. Gerek yenilenebilir enerji teknoloji ekipmanlarının finansmanı, gerekse proje kurulum finansmanlarının hükümet tarafından desteklenmesi önem arz etmektedir.

Yenilenebilir enerjinin geliştirilmesine yönelik teşvik araçları; tarife garantisi, prim garantisi, kredi ve sübvansiyonlar, vergi düzenlemeleri, kota uygulamaları, yeşil sertifikalar, ihale sistemi, net ölçümleme, yeşil enerji satın alımları, enerji üretim ödemesi, geri ödeme, öncelik hakkı gibi bazı uygulamalardan oluşmaktadır. Tarife/prim garantisi, yenilenebilir enerjinin yeni gelişim gösterdiği hemen her ülkede etkili olduğu için gerek AB ülkelerinde gerekse diğer gelişmiş ülkelerde en çok tercih edilen teşvik aracı olmuş ve yatırımcıları ilgili alana çekmeyi başarabilmiştir. Temel teşvik sistemlerinin yanı sıra hükümetler; vergi düzenlemeleri, hibeler, yumuşak krediler yoluyla da ilgili sektörü cazip hale getirmiştir. Gerek yenilenebilir enerji kaynaklarının gerekse bu kaynaklar için geliştirilmiş teşvik 
mekanizmalarının çeşitliliği, hangi yenilebilir enerji kaynağı için hangi teşvik mekanizmasının etkin olduğu sorusunu gündeme getirmektedir. Zira teşvikler, teorik olarak sınırsız olmayan kamu kaynaklarından finanse edilmektedir. Bu açıdan yenilebilir enerji yatırımlarını teşvik mekanizmalarından hangisinin ne düzeyde etkilediğinin tespiti, optimal teşvik mekanizmasının politika yapıcı tarafından geliştirilmesi açısından önemlidir. Dolayısıyla etkin teşvik mekanizmasının geliştirilmesi, revize edilmesi veya hangisinin uygulanacağına karar verilmesi, teşvik mekanizmalarının etki düzeyinin tespitini gerektirmektedir.

Yenilenebilir enerji çalışmaları, genellikle kullanılan araçların, politikaların, sistemlerin incelenmesi ve yenilenebilir enerji-ekonomik büyüme ilişkisi gibi konular üzerine odaklanmıştır. Ele alınan dönemde yenilenebilir enerjinin yeni gelişen bir piyasa olmasından dolayı yatırım maliyetlerinin yüksek olması, geri dönüşün uzun zaman alması ve girişimciler tarafından riskli bulunması gibi unsurlar, ilgili sektöre yönelik teşvik mekanizmaları aracılığıyla kamu politikaları geliştirilmesine yol açmıştır. Genel eğilimden farklı olarak, çalışmada kamu kaynakları ile finanse edilen teşviklerin etkinliğinin analiz edilmesi, etkin teşvik araçlarının tespit edilmesi açısından oldukça önemlidir. Teşvik mekanizmalarının güneş enerjisine yönelik yatırımlar üzerindeki etkisinin incelendiği bu çalışmada, teşvik mekanizmaları ve AB ülkelerindeki uygulama şeklini takiben yenilenebilir enerji teşvik araçları ile güneş enerjisi kurulu güç kapasitesi arasındaki ilişki, 28 ülke için 2001-2015 dönemini kapsayan yıllık verilerle dinamik panel yöntemi kullanılarak analiz edilmiştir.

\section{Kamu Teşvik Mekanizmaları ve AB Ülkelerinde Uygulanma Biçimleri}

Yenilenebilir enerjinin kullanımının artırılması için enerji arz güvenliği, ekonomik kalkınma ve emisyon salınımının azaltılmasına dair olguları içeren bazı hedefler belirlenmelidir. Bu hedeflere ulaşabilmek için ise şimdiki enerji sisteminin içerisinde var olan çeşitli engellerin, politika destekleri ile aşılması gerekmektedir (Turkenburg vd., 2012: 877). Temel amaç, yenilenebilir enerji teknolojilerinin enerji sistemleri içerisinde yayılımını ve entegrasyonunu hızlı bir şekilde başarmaktır. Bu amaca yönelik olarak geliştirilen politikaların, teşviklerin ve düzenlemelerin sınıflandırılmasına dair birkaç görüş bulunmakla birlikte (Turkenburg vd., 2012; Schallenberg-Rodriquez, 2017; Abolhosseini \& Heshmati, 2014; Kitzing vd., 2012; REN 21, 2016) bu çalışmada tüm teşvikleri içerisinde barındırması, diğer sınıflandırmalara göre daha kapsamlı olması ve üç ana başlık halinde tüm teşviklerin toplu bir biçimde incelenme imkanı sağlamasından dolayı IRENA (2012)'nın politika önerisi içerisinde yer alan sınıflandırma biçimi ele alınmış olup, Tablo 1'de destekleme ve teşvik araçlarına yer verilmiştir. 


\section{Tablo: 1}

\section{Yenilenebilir Enerji (YE) Destekleme ve Teşvik Araçları}

\begin{tabular}{|c|c|c|}
\hline Mali Teşvikler & Kamu Finansman Araçları & Teşvik Düzenlemeleri \\
\hline \multirow{3}{*}{$\begin{array}{l}>\text { Ödenekler/Yardımlar ve Garantiler } \\
\text { Enerji Üretim Ödemesi } \\
>\text { Geri Ödeme } \\
>\text { Vergi Düzenlemeleri }\end{array}$} & \multirow{3}{*}{$\begin{array}{l}\text { Yatırımlar } \\
>\text { Garantiler } \\
>\text { Kredi ve Sübvansiyonlar } \\
>\text { Kamu Satın Alımları }\end{array}$} & $\begin{array}{l}\text { Miktar Temelli Düzenlemeler } \\
\text { > YEP Standartları } \\
\text { > İhale Sistemi }\end{array}$ \\
\hline & & $\begin{array}{l}\text { Fiyat Temelli Düzenlemeler } \\
\text { > Tarife Garantisi (FiT) } \\
\text { > Prim Sistemi (FiP) } \\
\text { - Sabit Prim Sistemi } \\
\text { - Taban ve Tavan Prim Sitemi } \\
\text { - Değişken Prim Sistemi } \\
\end{array}$ \\
\hline & & $\begin{array}{l}\text { Kalite Temelli Düzenleme ve Teşvikler } \\
\text { > Yeşil Enerji Satın Alınması } \\
\text { > Yeşil Etiketleme } \\
\text { > Iletime Yönelik Teşvikler } \\
\text { > Net Ölçümleme } \\
\text { > Öncelik Hakkı }\end{array}$ \\
\hline
\end{tabular}

Kaynak: IRENA (2012)'den faydalanılarak yazarlar tarafindan oluşturulmuştur.

Yenilenebilir enerjiyi geliştirme hedefi, AB ülkelerinin de teşvik sistemlerini özendirici bir politika aracı olarak önemsemesine neden olmuştur. Bazı ülkeler mali teşvikler ve kamu finansman araçları ile ilgili alana destek sağlarken, bazı ülkeler teşvik düzenlemeleri aracılığıyla yenilenebilir enerjinin yaygınlaşmasını sağlamaktadır. Yenilenebilir enerji sektörleri içerisinde en çok destek stratejisi uygulamasına ve en eski tarihli uygulamaya elektrik sektörü sahiptir. Yenilenebilir elektriğge yönelik geliştirilen spesifik politika destekleri AB ülkeleri içerisinde sırasıyla Danimarka (1979), Portekiz (1988), Almanya (1989) ve Birleşik Krallık’ta (1989-90) ilk kez uygulama alanı bulmuş ve ilerleyen tarihlerde tüm AB ülkelerine yayılmıştır (Kitzing vd., 2012: 193). AB ülkeleri içerisinde en çok tercih edilen yenilenebilir enerji teşvik mekanizmaları tarife garantisi, prim garantisi, ihale sistemi ve yenilebilir portföy standartları/kota uygulamalarıdır. Çalışmanın uygulama kısmında yer alması nedeniyle vergi düzenlemeleri, krediler ve sübvansiyonlar hakkında da genel bilgilere yer verilmektedir.

\section{- Tarife Garantisi:}

Tarife sistemi, yapılan sınıflandırmalarda temel teşvik sistemi veya fiyat temelli teşvik sistemi içerisine dâhil edilmektedir. Fiyat temelli teşvik sistemi içerisinde sınıflandırılmasının altında, ilgili teşvik mekanizmasının birim başına belirli bir ödemeyi garanti altında tutması yatmaktadır. Tarife garantisi sistemi, yenilenebilir enerji teknolojisi yatırımlarını hızlandırmak için kullanılan teşvik politikasıdır. Yeni yenilenebilir enerji projelerinin geliştirilmesi için kullanılan, enerji arz yönlü bir politika özelliği taşımaktadır. Tarife garantisi sistemi, elektrik üreticisi açısından uzun dönemli satın alım garantisi sözleşmesi sunduğu için yatırımların risk payını azaltmaktadır. Tarife garantisi sisteminin başarılı olabilmesi için üç temel şartın yerine getirilmesi gerekmektedir: i) üretilen elektriğin şebeke ağına girişinin garanti altına alınması, ii) uzun süreli ve sabit satın alım sözleşmelerinin yapılması, iii) üretilen elektriğin birim başına düşen maliyetlerinin ve piyasa fiyatlarının üzerinde bir satın alım fiyatı belirlenmesi. Tarife garantisi politikasında ülkeden ülkeye farklılık göstermekle birlikte genellikle 10-25 yıl gibi uzun dönemli satın alım garantisi ve sözleşmesi bulunmakta ve $\mathrm{kW} / \mathrm{h}$ başına ödeme yapılmaktadır. Ödeme miktarı/tarife miktarı teknolojinin çeşidine, projenin büyüklüğüne, kaynağın kalitesine ve 
Kaya, H.İ. \& Y. Bayraktar (2021), "Kamu Teşvik Mekanizmalarının Yenilenebilir Enerji Kaynakları Üzerine Etkisi: AB Ülkeleri ve Türkiye'de Güneş Enerjisine Yönelik Dinamik Panel Veri Analizi”, Sosyoekonomi, 29(48), 181-204.

projenin yerine göre farklılık gösterebilmektedir. Politika yapıcılar ödeme seviyesini kurulum miktarına göre belirli yıllarda ayarlama hakkına sahiptir. Bazı ülkelerde tarife politikaları, yönetim prosedürlerinin kısa zamanda gerçekleştirilmesi, bürokrasinin azaltılması, proje maliyetlerinin minimize edilmesini de içermektedir (Mendoca, 2007; Couture vd., 2010: 6).

\section{- Prim Sistemi:}

$\mathrm{Bu}$ sistemde yenilenebilir enerji üreticisine elektrik piyasasında oluşan elektrik fiyatının üzerinde bir prim ödemesi gerçekleştirilmektedir. Prim ödemesinin belirlenmesinde sabit prim, değişken prim ve taban-tavan prim şeklinde farklı prim ödeme sistemleri bulunmaktadır (Held, 2014: 38-40):

$\checkmark$ Sabit Prim Sitemi: Prim, uzun dönemli ortalama elektrik fiyatlarına göre hesaplanmakta, aylık, haftalık ve günlük değişiklikler hesaba katılmamaktadır. Bu nedenle bu politika, tahmin edilebilir politika maliyeti sunmaktadir.

$\checkmark$ Değişken Prim Sistemi: Elektrik fiyatlarının seviyesine bağlı olan ve dinamik bir karakter sergileyen değişken prim sisteminde yenilenebilir enerji yatırımcıları elektrik piyasası fiyatlarının tüm riskine maruz kalmamaktadır. Prim seviyesi genellikle açık artırma prosedürlerine göre belirlenmektedir. Prim sisteminin uygulanması ve piyasada oluşan elektrik fiyatlarının yükselmesi halinde politika maliyetleri ile ilgili olarak kamu kesimi daha yüksek riske katlanmak durumundadır. Değişken prim sisteminde tarife belirlenmesinin birçok yolu bulunduğu için, değişken sistem, sabit tarife sistemine veya sabit prim sistemine yakın olabilmektedir. Hangi sisteme yakın olacağ hesaplama sırasında alınan referans değeri hesaplamasına göre değişiklik göstermektedir. Prim ödemesi hesaplanırken, elektrik üretiminin tamamının ağırlıklandırılması ve elektrik fiyatlarının uzun dönemli ortalamasının alınması durumunda, yenilenebilir enerji üreticileri piyasa fiyatları riskine maruz kalabilir ve bu yönüyle sabit prim ödemesi seçeneğine yaklaşılır. Bu durumun aksine eğer prim sistemi saatlik fiyatlara göre hesaplanır ve yalnızca rüzgâr enerjisi üretimine göre ağırlıklandırılırsa bu durumda piyasa riski daha düşük olacaktır ve böylelikle sabit tarife garantisi sistemine yaklaşılacaktır. Bu nedenle farklı prim tarifesi ve tarife sistemi seçenekleri birbirleriyle tamamen farklılık arz etmezler. Çünkü birinden diğerine geçişkenlik söz konusudur.

$\checkmark$ Taban ve Tavan Prim Sistemi: Bu sistemde taban ve tavan limitleri sabit bir prim olarak önceden belirlenmektedir. Kamu ve yatırımcı arasındaki risk dağıtımı ise (yatırımcı riski, politika maliyeti riski) sabit prim ve değişken prim arasında bir tarife oluşmasıyla sonuçlanmaktadır. Diğer sistemlerin aksine bu sistemde taban ve tavan primin açık artırma sisteminde belirlenmesi daha karmaşıktır.

Prim sistemi, diğer destekleme araçları ile karşılaştırıldığında bazı avantajlara sahiptir. İyi tasarlanmış bir tarife düzenlemesi maliyetleri sınırlayacak ve yenilikleri artıracaktır. Maliyet hesaplanmasının otomatik veya öngörülebilir ayarlamalar içermesi yatırım için yeterli güveni ve öngörüyü verecektir. Bu durum göz önünde bulundurulduğunda yatırımcılar açısından yeşil sertifikalara kıyasla 
Kaya, H.İ. \& Y. Bayraktar (2021), "Kamu Teşvik Mekanizmalarının Yenilenebilir Enerji Kaynakları Üzerine Etkisi: AB Ülkeleri ve Türkiye'de Güneş Enerjisine Yönelik Dinamik Panel Veri Analizi”, Sosyoekonomi, 29(48), 181-204.

yeni gelişen ve piyasası hazır olmayan teknolojiler için daha öngörülebilir bir kâr akışı oluşacaktır. Prim sistemi, -enerji değişimi ve çift yönlü kontratlar ileyenilenebilir enerjinin farklı piyasalara satılmasını ve değerinin artmasını sağlayacaktır. $\mathrm{Bu}$ durum yenilenebilir enerji üreticisinin üzerinde bask1 oluşmasına ve daha aktif bir piyasa katılımcısı olmasına neden olacaktır (EC, 2013: 8-9).

\section{- İhale Sistemi:}

İhale sistemi, miktar temelli bir yaklaşımdır. İhale sisteminde hükümetlerin çağrısına potansiyel yatırımcilar teklif verirler. Her teklif verme turunda, daha önceden belirlenen miktara ulaşılana kadar sunulan en düşük teklif seçilir. İhale sistemi genellikle teknoloji temelli bir teşvik mekanizmasıdır. Buna göre, örneğin rüzgâr projeleri, yine rüzgâr projelerine karşı rekabet etmektedir. Bu sistemde rüzgâr projesi ile biokütle projesinin rekabeti söz konusu değildir (Schallenberg-Rodriguez, 2017: 1423). Bu sistemde finansal destek toplam yatırım maliyeti için veya elektrik üretiminin birim miktarı başına verilebilir. İhale sistemi özellikle bağımsız konvansiyonel enerji üreticileri tarafından birçok ülkede kullanılan bir sistem olmakla birlikte, AB ülkelerinden Fransa ve Danimarka deniz rüzgâr enerji santrallerinde yenilenebilir enerjiyi teşvik etmek için bu sistemi kullanmıştır. İngiltere, 1991 yılında "Non-Fossil Fuel Obligation (NFFO)" ad1 altında bu sistemi ilk kullanan ülke olmuştur (Jacobs, 2009: 8).

İhale sisteminde üreticiler arasında oluşan rekabet sonucunda en düşük teklif sahibi ilgili ihaleyi kazandığı için maliyet açısından etkin bir sistemdir. Ayrıca ihale süreci ile ilgili kurumun doğrudan bir şekilde destek mekanizması altında üretilen elektrik miktarını kontrol edebilme yetisi bulunmaktadır (Jacobs, 2009: 8). Diğer taraftan ihale sisteminde teklif verenler açısından işlem maliyetlerinin varlığı, küçük oyuncuların ihaleye katılmakta zorlanması gibi bir olumsuzluğu da barındırmaktadır (IRENA \& CEM, 2015: 24).

\section{- YPS/Kota Uygulamaları:}

Yenilenebilir enerji portföy standartları, "kota mekanizması" olarak da isimlendirilen bir teşvik sistemidir. Bu sistemde elektrik arz edenlerin belirli bir oranda, yenilenebilir enerjiden üretilen elektriği alması zorunludur. Ayrıca bu sistem tüketiciler açısından tüketilen elektriğin belirli bir kısmını yenilenebilir kaynaklardan alınması şeklinde de uygulanabilir. YPS/Kota uygulaması tarife garantisi ile en yaygın kullanılan politikalardan biridir. Tarife politikaları fiyat temelli politikalar olarak öne çıkarken, YPS politikaları miktar temelli destekleme mekanizmasıdır. $\mathrm{Bu}$ teşvik aracı, yenilenebilir enerji kaynaklarından üretilen elektrik miktarının artırılmasını sağlamaya yöneliktir. Bu sistemin uygulanması için, firmalar üretilen elektrik birimi başına (örneğin $1 \mathrm{kw} / \mathrm{h}$ ) pazarlanabilir sertifika alırlar. Bu sertifikalara pazarlanabilir yeşil sertifikalar adı verilmektedir (Kaya, 2017: 73).

Tarife sisteminin aksine, bu sistemde devlet, belirli bir çıktı seviyesi belirlemekte ve ödenecek fiyatın piyasa tarafından belirlenmesine izin vermektedir. YPS/Kota sisteminde hangi yenilenebilir enerji teknolojisinden faydalanılacağına devlet karar vermez. Buna göre, 
Kaya, H.İ. \& Y. Bayraktar (2021), "Kamu Teşvik Mekanizmalarının Yenilenebilir Enerji Kaynakları Üzerine Etkisi: AB Ülkeleri ve Türkiye'de Güneş Enerjisine Yönelik Dinamik Panel Veri Analizi”, Sosyoekonomi, 29(48), 181-204.

teknoloji tercihinin piyasa tarafından yapılması uygun görülmektedir. YPS/Kota sisteminin temel özellikleri şu şekildedir (REEEP/UNIDO, 2013: 10-11):

$\checkmark$ Yenilenebilir enerjide yaşanan gelişmeye bağlı olarak zaman içerisinde belirlenen oranlarda artış yaşanabilir.

$\checkmark$ Firmalar uygulamada belirlenen miktarı satın almak yerine, belirli bir ceza ödemeyi tercih edebilirler.

$\checkmark$ Ağa girişte firmalar için herhangi bir öncelikli giriş şartı bulunmamaktadır.

$\checkmark$ Çıktı elde edilmesi için sistem pazarlanabilir yeşil sertifikalar tarafindan desteklenmekte, bu sertifika ile enerjiyi arz eden taraf yenilenebilir temelli enerji satın alabilmektedir. Bu sertifikalar enerji ile satılmakta veya çeşitli zamanlarda pazarlanmaktadir.

\section{- Vergi Düzenlemeleri:}

Vergi ile ilgili düzenlemeler yatırım, üretim ve tüketim açısından farklı olabilir. Vergi ile ilgili teşvikler, yenilenebilir enerji yatırımlarını artırmaya yönelik olabileceği gibi fosil yakıt kullanımının azaltılmasına yönelik teşvik mahiyetinde de olabilir. Bu durum doğrudan yenilenebilir enerji yatırımını etkilemese de fosil yakıt kullanımına yönelik ek vergilerin varlığı, kaynakların yenilenebilir enerji alanına yönlendirilmesine neden olabilecektir (Abolhosseini \& Heshmati, 2014: 880). Yenilenebilir enerjiyi teşvik etmeye yönelik; katma değer vergisi indirimi/muafiyeti, sermaye yatırımları için vergi muafiyeti, ithal ekipman vergi muafiyeti gibi vergi indirimi ve/veya muafiyeti çeşitleri bulunmaktadır. Vergi indirimleri ve/veya muafiyetleri genellikle diğer yenilenebilir enerji teşvik politikalarını (tarife garantisi vb.) desteklemek ve tamamlamak için kullanılan ve yenilenebilir enerji teknolojisi yatırımlarını etkileyebilecek güçlü ve esnek bir teşvik politikası aracıdır. Vergi düzenlemeleri, diğer temel teşvik politikaları ile kullanıldığında yatırımcılar üzerinde son derece etkili olabilmektedir (De Jager vd., 2011: 32).

\section{- Kredi ve Sübvansiyonlar:}

Kredi, yenilenebilir enerji yatırımlarının teşvik edilmesi amacıyla bir imtiyaz sözleşmesi aracılığıyla kalkınma bankalarından ya da hükümetler tarafından belirlenen kurumlardan uygun oranlarla gerçekleştirilen bir finansman biçimidir. Borç yükümlülüğü karşılığında yenilenebilir enerji şirketine ve/veya projeye bu şekilde finansman sağlanmaktadır (IRENA, 2012: 8). Yenilenebilir enerji teknolojilerinin maliyetlerinin yüksek olması yenilenebilir enerji üreticisi tarafından üretilen elektrik miktarına bağlı olarak verilen sübvansiyonları kullanılabilir bir teşvik aracı haline getirmektedir. Sübvansiyonlar birçok şekilde verilmekle birlikte genellikle yenilenebilir enerji üretimi için gerekli olan sabit sermaye teçhizatı için yapılmaktadır. Bazı ülkeler ekipman ve teçhizat için verdikleri sübvansiyonları, yalnızca ülke içerisinde üretilen ekipman ve teçhizat satın alınması durumunda gerçekleştirmektedir (APEC, 2012: 36). Yenilenebilir enerji yatırımlarının finansmanında sağlanabilecek uzun vadeli, belirli bir süre geri ödemesiz ve düşük faizli kredi imkânlarının varlığının yanı sıra sübvansiyonlar, yatırımcıyı teşvik eden diğer faktörler olarak görülmektedir. 
Yenilenebilir enerji kaynaklarına yönelik kullanılan teşvik mekanizmaları, farklı teknolojiler için aynı politikalar ve/veya aynı teknoloji için farklı politikalar şeklinde kullanılabilir. Uygulanan politika yenilenebilir enerjinin yayılmasını ve belirlenen hedeflere ulaşmasını sağlıyor ise izlenen politika etkindir. Kuşkusuz teşvik politikaları içerisinde en etkin politikanın belirlenmesi hem hedeflere hızla ulaşmak hem de topluma düşük maliyet yüklemesi açısından önemlidir. $\mathrm{AB}$ ülkelerinde en çok tercih edilen destekleme araçları tarife garantisi, prim garantisi, kota uygulamaları, ihale sistemi ve sübvansiyonlar olarak görülmektedir. Teşvik politikalarından hangisinin/hangilerinin uygulanacağına karar verme aşamasında teşvik politikalarının etkinlik düzeyi politika yapıcıya yol gösterecektir. Tablo 2 'de $\mathrm{AB}$ ülkelerinde uygulanan teşvik uygulamalarına yer verilmiştir.

Tablo: 2

\section{AB Ülkelerinde Yenilenebilir Enerji Teşvik Uygulamaları}

\begin{tabular}{|c|c|c|c|}
\hline & Elektrik (YE) & Isitma ve Soğutma (YE) & Ulaştırma (YE) \\
\hline Tarife Garantisi & $\begin{array}{l}\text { Almanya, Avusturya, Bulgaristan, } \\
\text { Birleşik Krallı, Çek Cumhuriyeti, } \\
\text { Finlandiya, Fransa, İrlanda, İspanya, } \\
\text { İtalya, Litvanya, Lüksemburg, } \\
\text { Macaristan, Malta, Polonya, } \\
\text { Portekiz, Slovakya, Güney Kıbrıs }\end{array}$ & Litvanya & क \\
\hline $\begin{array}{l}\text { Prim Garantisi } \\
\text { Sistemi }\end{array}$ & $\begin{array}{l}\text { Almanya, Çek Cumhuriyeti, } \\
\text { Danimarka, Estonya, Finlandiya, } \\
\text { Fransa, Hollanda, İspanya, İtalya, } \\
\text { Letonya, Lüksemburg, Macaristan, } \\
\text { Polonya }\end{array}$ & Danimarka, Finlandiya & - \\
\hline İhale Sistemi & $\begin{array}{l}\text { Almanya, Birleşik Krallık, } \\
\text { Danimarka, Fransa, Hollanda, İtalya, } \\
\text { Litvanya, Macaristan, Polonya, } \\
\text { Slovenya }\end{array}$ & - & - \\
\hline $\begin{array}{l}\text { Kota } \\
\text { Uygulaması/Yeşil } \\
\text { Sertifika }\end{array}$ & $\begin{array}{l}\text { Belçika, Birleşik Krallık, İsveç, } \\
\text { İtalya, Polonya, Romanya }\end{array}$ & - & $\begin{array}{l}\text { Almanya, Avusturya, Belçika, Bulgaristan, } \\
\text { Birleşik Krallık, Çek Cumhuriyeti, } \\
\text { Danimarka, Finlandiya, Fransa, Hollanda, } \\
\text { İrlanda, İspanya, İtalya, Letonya, Litvanya, } \\
\text { Lüksemburg, Macaristan, Malta, Polonya, } \\
\text { Portekiz, Romanya, Slovenya, Slovakya, } \\
\text { Güney Kıbrıs }\end{array}$ \\
\hline $\begin{array}{l}\text { Sübvansiyon } \\
\text { Uygulaması }\end{array}$ & $\begin{array}{l}\text { Almanya, Avusturya, Çek } \\
\text { Cumhuriyeti, Finlandiya, İsveç, } \\
\text { Litvanya, Lüksemburg, Macaristan, } \\
\text { Malta, Romanya, Slovenya, } \\
\text { Slovakya, Güney Kıbris }\end{array}$ & $\begin{array}{l}\text { Avusturya, Bulgaristan, Birleşik } \\
\text { Krallık, Çek Cumhuriyeti, Estonya, } \\
\text { Finlandiya, Fransa, Hollanda, } \\
\text { İrlanda, İtalya, Litvanya, } \\
\text { Lüksemburg, Macaristan, Malta, } \\
\text { Polonya, Slovenya, Slovakya, Güney } \\
\text { Kibris }\end{array}$ & Avusturya, Estonya, Litvanya, Macaristan \\
\hline Net Ölçümleme & Danimarka, Letonya, Güney Kıbrıs & - & - \\
\hline $\begin{array}{l}\text { Vergi Uygulamaları } \\
\text { (İade-Muafiyet- } \\
\text { İndirim) }\end{array}$ & $\begin{array}{l}\text { Birleşik Krallık, Fransa, Hollanda, } \\
\text { İsvec, Litvanya, Lüksemburg, } \\
\text { Polonya, Slovakya }\end{array}$ & Belçika, Danimarka & $\begin{array}{l}\text { Almanya, Avusturya, Belçika, Çek } \\
\text { Cumhuriyeti Danimarka, Finlandiya, Fransa, } \\
\text { Hollanda, İspanya, İsveç, Letonya, Litvanya, } \\
\text { Macaristan, Portekiz, Slovenya, Slovakya }\end{array}$ \\
\hline Kredi Uygulamaları & $\begin{array}{l}\text { Almanya, Danimarka, Hollanda, } \\
\text { Polonya }\end{array}$ & Almanya & - \\
\hline
\end{tabular}

Kaynak: Banja M. vd. (2017) tarafindan hazırlanan kaynaktan faydalanılarak yazarlar tarafindan düzenlenmiştir.

AB ülkelerinde yenilenebilir enerji yatırımlarını en fazla tetikleyen teşvik mekanizmaları, tarife ve prim garantisi sistemidir. 18 AB ülkesinde uygulanan tarife garantisi sistemi, Almanya ve eksenindeki ülkelerde uygulanmasına karşın özellikle Kuzey Avrupa ülkelerinin bir bölümünde uygulanmamaktadır. Danimarka ve İsveç gibi yenilenebilir enerji kaynaklarını yüksek oranda kullanan ülkelerin temel teşvik sistemlerinden olan tarife garantisini kullanmamaları dikkat çekicidir. Prim garantisi uygulamasını kullanan 13 ülke bulunmaktadır. Kota uygulaması ise görece daha az tercih 
Kaya, H.İ. \& Y. Bayraktar (2021), "Kamu Teşvik Mekanizmalarının Yenilenebilir Enerji Kaynakları Üzerine Etkisi: AB Ülkeleri ve Türkiye'de Güneş Enerjisine Yönelik Dinamik Panel Veri Analizi”, Sosyoekonomi, 29(48), 181-204.

edilen bir teşvik aracı olarak görülmekte ve 6 AB ülkesi (Birleşik Krallık, İsveç, Belçika, İtalya, Romanya ve Polonya) tarafindan kullanılmaktadır. İhale sistemi, Almanya, Birleşik Krallık, Danimarka, Fransa, Hollanda, İspanya, İtalya, Litvanya, Macaristan, Polonya ve Slovenya olmak üzere 10 ülkede kullanılmaktadır. Birincil teşvik sistemi olarak kullanılan Net Ölçümleme/Faturalandırma mekanizması ise Danimarka, Letonya ve Güney Kıbrıs olmak üzere 3 ülkede kullanılmaktadır. Kota uygulaması/yeşil sertifika sistemi ise 6 AB ülkesi tarafından tercih edilmektedir. Birincil teşvik araçları ile yenilenebilir enerjinin teşvik edilmesi için ikincil destek mekanizmaları da AB ülkelerinde oldukça yaygın kullanılan mekanizmalardır. İkincil mekanizma olarak değerlendirilen yatırım sübvansiyonları $13 \mathrm{AB}$ ülkesinde kullanılmaktadır. Sübvansiyonlar yenilenebilir elektriğe ek olarak 1sıtma/soğutma ve ulaştırma sektörlerinde de birçok ülke tarafından tercih edilen teşvik araçlarından biridir. Düşük faiz uygulaması, yenilenebilir enerji yatırımlarının artırılması için uygulanan bir diğer teşvik aracıdır. Bu uygulamada hükümetler yenilenebilir enerji yatırımları için piyasa faiz oranından daha düşük faiz oranı belirleyerek yatırımcının daha uygun maliyetle borçlanmasını sağlamanın yanı sıra yatırımcıların uzun süre geri ödeme yapmadan bu kaynaktan faydalanmaları sağlanmaktadır. Yenilenebilir enerjiyi teşvik etmek için hükümetler, mali teşvikler politikaları da geliştirmiştir. Bu çerçevede vergi oranlarını düşük tutarak veya vergi muafiyeti sağlanarak yatırımcıların maliyetleri düşürülmeye çalışılmaktadır. AB üyesi 8 ülke yenilenebilir enerjinin desteklenmesi kapsamında vergi uygulamalarına başvurmaktadır.

\section{AB Ülkelerinde Yenilenebilir Enerjinin Görünümü}

Yenilenebilir enerjiye yönelik artan küresel ilginin ateşi, AB ülkeleri tarafından yakılmıştır. AB enerji politikasının temelini tüketicilere ucuz, yüksek kalitede ve kesintisiz enerji sağlayabilmek oluşturmaktadır. AB'nin enerji politikasının hedefleri; rekabet gücü, enerji arz güvenliği ve çevrenin korunması arasında bir denge sağlamak, toplam enerji tüketiminde kömürün payını korumak, doğalgazın payını artırmak, nükleer enerji santralleri için azami güvenlik şartları tesis etmek ve yenilenebilir enerji kaynaklarının payını artırmak şeklinde sıralanabilir (Candan, 2004: 3).

$\mathrm{AB}$ ülkeleri yenilenebilir enerjinin kullanımını yaygınlaştırabilmek için dünyaya örnek olan politikalar ve uygulamalar geliştirmişlerdir. AB ülkeleri, Ulusal Yenilenebilir Enerji Eylem Planları içerisinde yenilenebilir enerji hedeflerine yer vermişler ve hedeflerine ulaşabilmek için izleyecekleri yol haritalarını belirtmişlerdir. AB ülkeleri; 2020, 2030, 2040 ve 2050 yılına yönelik hedefler belirlemiştir. Bazı ülkeler ise 2050 yılına gelindiğinde elektrik tüketiminin tamamını yenilenebilir enerji kaynaklarından karşılamak gibi iddialı hedefler belirlemiştir. AB ülkeleri arasında toplam enerji tüketimi içerisinde yenilenebilir enerji kaynaklarının payına yönelik en iddialı hedefler belirleyen ülkeler; Letonya (\%40), Finlandiya (\%38), Avusturya (\%34), Portekiz (\%31) ve Danimarka (\%30) olmuştur. Bu ülkeler 2020 yılına kadar bu hedeflere ulaşmayı amaçlamaktadır. Bu ülkelerin dışında Fransa 2030 yılına yönelik olarak toplam enerji tüketimi içerisinde $\% 32$ ve elektrik üretimi içerisinde \%40 oranında hedef belirlemiştir. Almanya ise 2030, 2040 ve 2050 hedeflerini sırasıyla \%45, \%60 ve \%80 olarak belirlemiştir. AB ülkeleri içerisinde en iddialı hedef Hollanda tarafından belirlenmiştir. Hollanda'nın 2015 yılında toplam enerji arzı içerisinde 
Kaya, H.İ. \& Y. Bayraktar (2021), "Kamu Teşvik Mekanizmalarının Yenilenebilir Enerji Kaynakları Üzerine Etkisi: AB Ülkeleri ve Türkiye'de Güneş Enerjisine Yönelik Dinamik Panel Veri Analizi”, Sosyoekonomi, 29(48), 181-204.

yenilenebilir enerjinin oranı \%14 iken 2050 yılına yönelik hedefini \%100 olarak ilan etmiştir (CEER, 2017: 32).

AB petrol ihtiyacının \%84'ünü, doğalgaz ihtiyacının \%64'ünü ve toplamda enerji ihtiyacının \%55'ini ithal etmektedir. Bu durum Avrupa'yı enerji bağımlısı bir bölge haline getirmektedir. Bu nedenle Avrupa Birliği üyesi ülkeler enerji arz güvenliğini sağlayabilmek ve enerjide dışa bağımlılığı ortadan kaldırabilmek amacıyla yenilenebilir enerji kaynaklarına özel önem atfetmektedir. Avrupa Birliği’nin enerji politikalarının temelinde yer alan sürdürülebilirlik ilkesi neticesinde yerli ve yenilenebilir kaynaklardan enerji elde etmek için AB üyesi ülkeler son dönemlerde artan oranda yatırımlar gerçekleştirmektedir. Yatırımlar neticesinde AB ülkelerinin kurulu güç kapasitelerinde büyük oranlı artışın yaşandığını Tablo 3 incelendiğinde görmek mümkündür.

Tablo: 3

AB Üyesi Ülkelerin (AB-28) Yenilenebilir Enerji Kurulu Güç Kapasitesi (2000-2016/MW)

\begin{tabular}{|c|c|c|c|c|c|c|c|c|c|c|}
\hline & $\mathbf{2 0 0 0}$ & $\mathbf{( \% )}$ & $\mathbf{2 0 0 5}$ & $\mathbf{( \% )}$ & $\mathbf{2 0 1 0}$ & $\mathbf{( \% )}$ & $\mathbf{2 0 1 5}$ & $\mathbf{( \% )}$ & $\mathbf{2 0 1 6}$ & $\mathbf{( \% )}$ \\
\hline Rüzgâr & 12.710 & 9,3 & 40.325 & 22,6 & 84.358 & 32,1 & 141.476 & 35,4 & 154.123 & 36,5 \\
\hline Güneş & 177 & 0,1 & 2.279 & 1,3 & 30.717 & 11,7 & 97.289 & 24,3 & 103.357 & 24,5 \\
\hline Hidroelektrik & 116.038 & 84,8 & 119.407 & 67,2 & 123.155 & 46,7 & 127.346 & 31,8 & 128.955 & 30,7 \\
\hline Biokütle & 7.953 & 5,8 & 15.925 & 8,9 & 24.927 & 9,5 & 33.978 & 8,5 & 35.032 & 8,3 \\
\hline Toplam & 136.878 & 100 & 177.936 & 100 & 263.157 & 100 & 400.089 & 100 & 421.467 & 100 \\
\hline
\end{tabular}

Kaynak: IRENA, Data\&Statistics, Query Tool, (https://www.irena.org/Statistics/Download-Data) verilerinden faydalanilarak oluşturulmuştur.

AB-28 ülkeleri yenilenebilir enerji kurulu güç kapasitesinde önemli oranda artış yaşamıştır. 2000 yılında AB-28 ülkelerinin toplam yenilenebilir enerji kurulu güç kapasitesi (jeotermal enerji hariç) 136.878 MW iken 2016 yılında bu miktar üç katın üzerinde bir artış göstererek 421.467 MW'ye ulaşmıştır. Bu artışın gerisinde özellikle rüzgâr ve güneş enerjisi kurulu güç kapasitesi yatmaktadır. Rüzgâr ve güneş enerjisi hemen her $A B$ ülkesinde teşvik edilen yenilenebilir enerji kaynağıdır. Rüzgâr enerjisi kurulu güç kapasitesi 2000 yılında 12.710 MW iken 2016 yılına gelindiğinde bu miktar 154.123 MW'ye çıkmıştır. Diğer taraftan güneş enerjisi kurulu gücü de benzer şekilde 177 MW'den 103.357 MW'ye çıkmıştır. Bu artışlarda yenilenebilir enerji yatırımlarına uygulanan başarılı teşvik sistemlerinin önemi büyüktür. Diğer taraftan biokütle üzerine özel olarak uygulanan politikaların da doğru kullanılması sonucunda biokütle kurulu güç kapasitesi 2000-2016 yılları arası dört katın üzerinde artış göstermiştir. Yenilenebilir enerji kaynaklarının toplam yenilenebilir enerji kapasitesi içerisindeki oranlarında da yıllar içerisinde önemli değişim yaşanmıştır. 2000 yılında yenilenebilir enerji kaynakları içerisinde hidroelektrik \%84,7'lik payı ile en önemli kaynak iken 2016 yılına gelindiğinde rüzgâr enerjisi \%36,5 pay ile en yüksek orana sahip kaynak olmayı başarmıştır. Güneş enerjisi ise 2000 yılında \%0,1'lik pay ile en düşük paya sahip yenilenebilir enerji kaynağı iken gerek teşvik mekanizmalarının etkinliği gerekse güneş enerjisi maliyetlerinin düşmesi neticesinde payını artırarak $\% 24,5^{\prime}$ lik bir orana ulaşmıştır. 
Kaya, H.İ. \& Y. Bayraktar (2021), “Kamu Teşvik Mekanizmalarının Yenilenebilir Enerji Kaynakları Üzerine Etkisi: AB Ülkeleri ve Türkiye'de Güneş Enerjisine Yönelik Dinamik Panel Veri Analizi”, Sosyoekonomi, 29(48), 181-204.

\section{Literatür Çalışmaları}

Yenilenebilir enerji üzerine yapılan çalışmalar, teşvik araçlarının teorik olarak incelendiği, ampirik olarak ise büyüme, istihdam, cari açık gibi değişkenlerle ilişkisi üzerine odaklanan geniş bir yelpazeye sahiptir. Teşvik mekanizmalarının etkinlik düzeyinin belirlenmesi, kamu kaynaklarının en etkin teşvik mekanizması aracılığıyla kullanılmasını sağlayarak toplumsal faydayı yükseltecektir. Bu bağlamda pek çok faktörden etkilenen ve yeni teknoloji yatırımları gerektirdiği için yatırımcı açısından riskli görülen yenilenebilir enerjinin yaygınlaştırılması için geliştirilen teşvik araçlarının etkinliğinin araştırılması, yenilebilir enerjinin artan önemine bağlı olarak son yıllarda çalışmalara konu olmaktadır.

Tablo: 4

\section{Teşvik Mekanizmaları-Yenilenebilir Enerji İlişkisi Üzerine Literatür İncelemesi}

\begin{tabular}{|c|c|c|c|c|}
\hline Yazarlar & Ülke & Dönem & Yöntem & Sonuçlar \\
\hline $\begin{array}{l}\text { Carley } \\
(2009)\end{array}$ & $\begin{array}{l}48 \text { ABD } \\
\text { Eyaleti }\end{array}$ & $\begin{array}{l}1998 \\
2006 \\
\end{array}$ & $\begin{array}{c}\text { Panel Veri } \\
\text { Analizi } \\
\end{array}$ & Tüm politik ve çevresel kurumlar, anlamlı ve pozitif olarak etkilemektedir. \\
\hline $\begin{array}{c}\text { Johnstone vd. } \\
\text { (2010) }\end{array}$ & $\begin{array}{l}25 \\
\text { OECD } \\
\text { Ülkesi }\end{array}$ & $\begin{array}{l}1978 \\
2003\end{array}$ & $\begin{array}{l}\text { Panel Veri } \\
\text { Analizi }\end{array}$ & $\begin{array}{l}\begin{array}{l}\text { Politika Değişkenleri yenilenebilir enerji teknolojilerinin gelişiminde önemli rol } \\
\text { oynamaktadır. }\end{array} \\
\text { Vergi teşvikleri ve gönüllü programların YE teknoloji yeniliği üzerinde etkisi yoktur. }\end{array}$ \\
\hline $\begin{array}{c}\text { Marques vd. } \\
\quad(2010)\end{array}$ & $\begin{array}{l}24 \\
\text { Avrupa } \\
\text { Ülkesi }\end{array}$ & $\begin{array}{l}1990 \\
2006\end{array}$ & $\begin{array}{c}\text { Panel Veri } \\
\text { Analizi }\end{array}$ & AB 2001 Direktifleri ile YE tüketimi arasında anlamlı ilişki bulunmuştur. \\
\hline $\begin{array}{c}\text { Yin \& Powers } \\
\quad(2010)\end{array}$ & $\begin{array}{l}50 \text { ABD } \\
\text { Eyaleti }\end{array}$ & $\begin{array}{l}1993 \\
2006\end{array}$ & $\begin{array}{c}\text { Panel Veri } \\
\text { Analizi }\end{array}$ & $\begin{array}{l}\text { YPS farklı teknolojilere göre pozitif veya negatif etkilemektedir. } \\
\text { Yeşil Üretim Seçeneği pozitif etkilemektedir. } \\
\text { Net ölçümleme ve kamu fonu ile negatif ilișki bulunmuştur. }\end{array}$ \\
\hline $\begin{array}{l}\text { Marques \& } \\
\text { Fuinhas } \\
\text { (2011) }\end{array}$ & $\begin{array}{l}24 \mathrm{AB} \\
\text { Ülkesi }\end{array}$ & $\begin{array}{l}1990 \\
2006\end{array}$ & $\begin{array}{c}\text { Dinamik } \\
\text { Panel Veri }\end{array}$ & $\begin{array}{l}\text { Bir önceki dönemdeki YE kullanım oranı ile şimdiki kullanım oranı arasında pozitif ve anlamlı } \\
\text { olduğu sonucuna ulaşılmıştır. }\end{array}$ \\
\hline $\begin{array}{l}\text { Zhao vd. } \\
(2013)\end{array}$ & $\begin{array}{c}122 \\
\text { Ülke }\end{array}$ & $\begin{array}{l}1980 \\
2010\end{array}$ & $\begin{array}{l}\text { Panel Veri } \\
\text { Analizi }\end{array}$ & $\begin{array}{l}\text { YE elektrik politikalarının YE elektrik üretimini teşvik etmekte önemli bir rol oynadığı ancak } \\
\text { politika sayısı arttıkça etkinliğin azaldığı sonucuna ulaşılmıştır. } \\
\text { Tüm kaynaklara yönelik yatırımlarda yalnızca tarife garantisi ve yatırım teşvikleri etkilidir. }\end{array}$ \\
\hline $\begin{array}{c}\text { Jenner vd. } \\
(2013)\end{array}$ & $\begin{array}{l}23 \mathrm{AB} \\
\text { Ülkesi }\end{array}$ & $\begin{array}{l}1990 \\
2011 \\
\end{array}$ & $\begin{array}{c}\text { Panel Veri } \\
\text { Analizi }\end{array}$ & $\begin{array}{l}\text { Tarife garantisi politikalarının fotovoltaik (güneş) enerjinin gelişimini etkilediği tespit } \\
\text { edilirken, rüzgâr enerjisi ile ilgili istatistiki olarak anlamlı bir ilişki tespit edilememiştir. }\end{array}$ \\
\hline $\begin{array}{l}\text { Eyraud vd. } \\
\quad(2013)\end{array}$ & $\begin{array}{c}35 \\
\text { Ülke }\end{array}$ & $\begin{array}{l}2000 \\
2010\end{array}$ & $\begin{array}{c}\text { Panel Veri } \\
\text { Analizi }\end{array}$ & $\begin{array}{l}\text { Yeşil yatırımlar yüksek fosil yakıt fiyatları, düşük faiz oranları ve sağlam bir finansal sistemle } \\
\text { doğrudan ilişkilidir. } \\
\text { Tarife garantisi sistemi gibi bazı politika araçlarının yeşil yatırımlar üzerinde olumlu ve } \\
\text { belirgin bir etkiye sahip olduğu sonucuna ulaşılmıştır. }\end{array}$ \\
\hline $\begin{array}{l}\text { Smith \& } \\
\text { Urpelainen } \\
\text { (2014) }\end{array}$ & $\begin{array}{l}26 \\
\text { Sanayi } \\
\text { Ülkesi }\end{array}$ & $\begin{array}{l}1979 \\
2005\end{array}$ & $\begin{array}{c}\text { Panel Veri } \\
\text { Analizi }\end{array}$ & $\begin{array}{l}\text { Tarife miktarlarındaki kWH başına } 1 \text { CENT/ } \$ \text { 'lı artışın toplam elektrik üretimi içerisindeki } \\
\text { YE payını \%0,11 oranında artırdığı sonucuna ulaşılmıştır. Tarife garantisi politikaları, YE } \\
\text { elektrik üretimini artırmanın etkili bir yoludur. }\end{array}$ \\
\hline $\begin{array}{l}\text { Bolkesjo vd. } \\
\quad(2014)\end{array}$ & $\begin{array}{c}5 \text { Avrupa } \\
\text { Ülkesi }\end{array}$ & $\begin{array}{l}1990 \\
2012\end{array}$ & $\begin{array}{c}\text { Panel Veri } \\
\text { Analizi }\end{array}$ & $\begin{array}{l}\text { Tarife garantisi, fotovoltaik ve kara rüzgâr enerjisinin yaygınlaşmasını etkilemektedir. YE } \\
\text { portföy standartlarının elektrik üretimi için kullanılan biyoenerjinin gelişimini anlamlı ve } \\
\text { pozitif olarak etkilediği sonucuna ve ihale sisteminin kara rüzgâr enerjisi gücünün artmasına } \\
\text { katkı sağladığı sonucuna ulaşılmıştır. }\end{array}$ \\
\hline $\begin{array}{l}\text { Polzin vd. } \\
\text { (2015) }\end{array}$ & $\begin{array}{c}\text { OECD } \\
\text { Ülkeleri }\end{array}$ & $\begin{array}{l}2000 \\
2011\end{array}$ & $\begin{array}{c}\text { Panel } \\
\text { Regresyon }\end{array}$ & $\begin{array}{l}\text { Daha az gelişmiş YE teknolojilerine yönelik kurumsal yatırım koşullarını iyileştirebilmek } \\
\text { adına tavsiye edilebilir politika araçları olarak tarife garantisi gibi ekonomik ve mali } \\
\text { teşviklerin faydalı olduğu görülmüştür. }\end{array}$ \\
\hline $\begin{array}{l}\text { Kilınc Ata } \\
\text { (2016) }\end{array}$ & $\begin{array}{l}27 \mathrm{AB} \\
\text { Ülkesi \& } \\
50 \mathrm{ABD} \\
\text { Eyaleti }\end{array}$ & $\begin{array}{l}1990 \\
2008\end{array}$ & $\begin{array}{c}\text { Panel Veri } \\
\text { Analizi }\end{array}$ & $\begin{array}{l}\text { YE politika araçlarının YE kaynaklarının kullanımında önemli etkisi olduğu sonucuna } \\
\text { ulaşılmıştır. } \\
\text { Kota uygulaması etkinsiz, diğer uygulamalar etkilidir. } \\
\text { Fiyat temelli politikaların, miktar temelli politikalara göre daha etkili olduğunu ifade } \\
\text { etmektedir. }\end{array}$ \\
\hline $\begin{array}{c}\text { Crago \& } \\
\text { Chernnyakhovskiy } \\
(2017)\end{array}$ & $\begin{array}{c}\text { ABD } \\
\text { Eyaletleri }\end{array}$ & $\begin{array}{l}2005 \\
2012\end{array}$ & $\begin{array}{c}\text { Panel Veri } \\
\text { Analizi }\end{array}$ & $\begin{array}{l}\text { Para iadesinin (rebate) konutlarda güneş enerjisi kullanımını artıran en etkili sistem olduğu } \\
\text { sonucuna ulaşmışlardır. }\end{array}$ \\
\hline $\begin{array}{l}\text { Romano vd. } \\
\qquad(2017)\end{array}$ & $\begin{array}{l}56 \\
\text { Ülke }\end{array}$ & $\begin{array}{l}2004 \\
2013\end{array}$ & $\begin{array}{c}\text { Panel Veri } \\
\text { Analizi }\end{array}$ & $\begin{array}{l}\text { Orta gelirli ülkelerde kamu yatırımlarının YE yatırımlarını pozitif etkilediği ancak düzenleme } \\
\text { politikalarının YE yatırımlarını etkilemede yetersiz olduğu sonucuna ulaşmışlardır. Yüksek } \\
\text { gelirli ülkelerde ise mali politikalar ve kamu yatırımlarının YE yatırımlarını teşvik ettiği ancak } \\
\text { düzenleme politikaları ile YE üretimi arasında anlamlı bir ilişki olmadığını ortaya } \\
\text { koymuşlardır. }\end{array}$ \\
\hline $\begin{array}{l}\text { Nicolini \& } \\
\text { Tavoni } \\
(2017)\end{array}$ & $\begin{array}{l}5 \mathrm{AB} \\
\text { Ülkesi }\end{array}$ & $\begin{array}{l}1990 \\
2010\end{array}$ & $\begin{array}{l}\text { Panel Veri } \\
\text { Analizi }\end{array}$ & $\begin{array}{l}\text { Tarife miktarlarında \%1'lik artış, teşvik edilmiş yenilenebilir enerji üretimini } \% 0,4-1 \\
\text { aralığında artırmaktadır. } \\
\text { Yenilenebilir enerji kaynaklarından elektrik üretiminin desteklemesinde kısa dönemde tarife } \\
\text { garantisi sistemi, yeşil sertifikalara kıyasla daha etkilidir. }\end{array}$ \\
\hline
\end{tabular}


Kaya, H.İ. \& Y. Bayraktar (2021), "Kamu Teşvik Mekanizmalarının Yenilenebilir Enerji Kaynakları Üzerine Etkisi: AB Ülkeleri ve Türkiye'de Güneş Enerjisine Yönelik Dinamik Panel Veri Analizi”, Sosyoekonomi, 29(48), 181-204.

\begin{tabular}{|c|c|c|c|c|}
\hline $\begin{array}{l}\text { Li vd. } \\
\text { (2017) }\end{array}$ & $\begin{array}{l}21 \mathrm{AB} \\
\text { Ülkesi }\end{array}$ & $\begin{array}{l}1996 \\
2013\end{array}$ & $\begin{array}{c}\text { Panel Veri } \\
\text { Analizi }\end{array}$ & $\begin{array}{l}\text { Tarife garantisinin YE portföy standartlarına (YPS) göre güneş ve rüzgâr enerjisinde daha } \\
\text { etkili olduğu, YPS'nin ise rüzgâr enerjisinde etkili olduğu sonucuna ulaşlııștır. Vergi } \\
\text { teşvikleri hariç, diğer ekonomik enstrümanların fotovoltaik enerjinin gelişmesinde etkisiz } \\
\text { olduğu fakat rüzgâr enerjisine yönelik etkili olduğu sonucuna ulaşı1mıştır. }\end{array}$ \\
\hline
\end{tabular}

Yenilenebilir enerjinin yaygınlaşmasını destekleyen politikalar ve teşvik sistemlerinin etkilerine yönelik yapılan çalışmalar, genel olarak AB ülkeleri ve gelişmiş ülkeleri incelemektedir. AB ülkeleri üzerine yapılan çalışmalarda genel eğilim, teşvik politikalarının (özellikle tarife garantisi politikası) yenilenebilir enerjinin gelişimini ve yaygınlaşmasını desteklediği yönündedir. Nicolini \& Tavoni (2017) kısa dönemde tarife garantisi sisteminin, yeşil sertifikalara kıyasla daha etkili olduğunu belirterek gerek kısa dönemde gerekse uzun dönemde tüm politika araçlarının yenilenebilir enerjinin gelişiminde etkili olduğunu ifade etmektedir. Jenner vd. (2013) ise tarife garantisi politikalarının fotovoltaik (güneş) enerjisinin gelişimini etkilediğini ancak rüzgâr enerjisi ile istatiksel olarak anlamlı bir ilişki tespit edilemediği sonucuna ulaşmışlardır. Buna karşın Li vd. (2017) ise vergisel teşvikler hariç diğer ekonomik enstrümanların fotovoltaik enerjinin gelişmesinde etkisiz olduğunu belirtmişlerdir. Bolkesjo vd. (2014) ise tarife garantisinin fotovoltaik ve rüzgâr enerjisinin gelişiminde, YPS sisteminin biyoenerjinin gelişiminde, ihale sisteminin ise kara rüzgâr enerjisinin gelişiminde etkili olduğunu ifade etmektedir. Yin \& Powers (2010) ise 50 ABD eyaleti üzerine gerçekleştirdiği çalışmada, YPS politikasının yenilenebilir enerji gelişiminde pozitif etkiye sahip olduğu, net ölçümleme ve kamu fonlarının ise negatif ilişkili olduğu sonuca ulaşmıştır. Kılınç Ata (2016) ise yenilenebilir kaynaklardan elektrik üretimi için tarife garantisi, ihale sistemi ve vergi teşvikleri gibi politika araçlarının etkili olduğunu, kota uygulamasının ise etkisiz olduğu sonucuna ulaşmıştır. Marques vd. (2010), enerji bağımlılığını azaltma çabasının yenilenebilir enerji kullanımını teşvik ettiği ve bu nedenle AB'nin yenilenebilir enerji kaynakları kullanımını teşvik eden direktiflerin olumlu sonuçlar getireceğini öne sürmektedir. Marques \& Fuinhas (2011) ise bir önceki dönemdeki yenilenebilir enerji kullanım oranının, şimdiki kullanım oranına etkisinin pozitif ve anlamlı olduğu sonucuna ulaşmıştır. Carley (2009)'in ABD eyaletleri üzerine yaptığı çalışmanın bulguları ise vergi teşviklerinin yenilenebilir enerjide düşüşe neden olabileceği yönündedir. Bu durumun nedeni ise çok açık olmamakla birlikte, sübvansiyonların büyük üreticileri cezbetmesi, vergilerin ise ABD eyaletlerinde küçük üreticilere ve hane halkına yönelik olması şeklinde ifade edilmiştir. Crago \& Chernnyakhovskiy (2017), ABD eyaletlerinde konutlarda güneş enerjisi kullanımına yönelik çalışmalarında para iadesinin (rebate) konutlarda güneş enerjisi kullanımını artıran en etkili sistem olduğu sonucuna ulaşmışlardır. AB ve ABD üzerine yapılan çalışmalara ek olarak, diğer gelişmiş ülkeler üzerine yapılan değerlendirmelerde de tarife garantisinin etkinliği üzerinde durulmaktadır. Eyraud vd. (2013), karbon fiyatlandırması ve tarife garantisi sistemi gibi politika araçlarının yeşil yatırımlar üzerinde olumlu ve belirgin etkisi olduğu; Smith \& Urpelainen (2014) ise tarife miktarlarındaki kWh başına 1 cent/\$'lik artışın toplam elektrik üretimi içerisindeki yenilenebilir enerjinin payının \%0,11 oranında artırdığı sonucuna ulaşmışlardır. Zhao vd. (2013) tarafından 122 ülke üzerine yapılan çalışmada, ülkelerde uygulanan politikaların artmasının politikaların etkinliğini azaltacağını, politika etkinliğinin enerji kaynağına göre değişkenlik gösterdiğini ve tüm yenilenebilir enerji kaynakları için teşvik mekanizmaları içerisinde yalnızca yatırım teşviklerinin ve tarife garantilerinin etkili olduğu sonucunu bulmuşlardır. OECD ülkelerine yönelik Johnstone vd. 
Kaya, H.İ. \& Y. Bayraktar (2021), "Kamu Teşvik Mekanizmalarının Yenilenebilir Enerji Kaynakları Üzerine Etkisi: AB Ülkeleri ve Türkiye'de Güneș Enerjisine Yönelik Dinamik Panel Veri Analizi”, Sosyoekonomi, 29(48), 181-204.

(2010) politika araçlarının yenilenebilir enerji teknolojilerine yönelik yenilikler açısından etkili olduğunu, Polzin vd. (2015) ise daha az gelişmiş yenilenebilir enerji teknolojilerine yönelik kurumsal yatırım koşullarını iyileştirebilmek için tarife garantisi gibi ekonomik ve mali teşviklerin faydalı olduğu bulgusuna ulaşmıştır. Romano vd. (2017), 56 ülkeyi yüksek gelirli ülkeler ve orta gelirli ülkeler olarak ikiye ayırmıştır. Orta gelirli ülkelerde kamu yatırımlarının yenilenebilir enerji yatırımlarını pozitif etkilediği ancak düzenleme politikalarının yenilenebilir enerji yatırımlarını etkilemede yetersiz olduğu sonucuna ulaşmışlardır. Yüksek gelirli ülkelerde ise mali politikalar ve kamu yatırımlarının yenilenebilir enerji yatırımlarını teşvik ettiği ancak düzenleme politikaları ile yenilenebilir enerji üretimi arasında anlamlı bir ilişki olmadığını ortaya koymuşlardır.

Literatür bulguları incelendiğinde genel eğilim, teşvik politikalarından tarife garantisinin yenilenebilir enerji yatırımlarını pozitif etkilediği yönündedir ancak teşvik mekanizmalarının etkinliği, yenilenebilir enerji kaynağına göre değişkenlik gösterebilmektedir. Literatürdeki çalışmaların geneli, teşvik mekanizmaları ile yenilenebilir elektrik üretimi ilişkisi üzerine yoğunlaşmış, bir kısım çalışmalar ise yenilenebilir enerji kaynaklarını tek tek incelemiştir. Bu çalışma ise dinamik panel veri analizini kullanması, diğer çalışmalardan farklı olarak yenilenebilir enerji oranı yerine güneş enerjisi kurulu güç kapasitesi eklemelerini bağımlı değişken alması ve Türkiye'nin de dahil olduğu 28 ülke için teşvik politikalarına güneş enerjisi yatırımlarının verdiği tepkinin ölçülmesi yönüyle ayrışmaktadır.

\section{Veri Seti, Model ve Metodoloji}

Çalışmada, 27 AB ülkesi ve Türkiye için bağımsız değişkenlerin, güneş enerjisi kurulu güç kapasitesindeki yıllık net eklemeler üzerindeki etkisi dinamik panel veri analizi ile tahmin edilmiştir. Dinamik Panel veri analizi için tek aşamalı ve iki aşamalı Arellano Bond Genelleştirilmiş Momentler Metodu (Panel GMM) kullanılmıştır.

Analizde yer alan değişkenlere ait veriler Dünya Bankası'nın Ekonomik Kalkınma Göstergeleri veri tabanı, IRENA veri tabanı ve IEA / IRENA Ortak Politika ve Önlemler veri tabanından derlenmiştir. Çalışmada ele alınan ülke grubu AB-27 ülkeleri ve Türkiye' dir. AB ülkeleri içerisinde Güney Kıbrıs yeterli veri bulunmadığı için analize dâhil edilmemiştir. Çalışmada, sağlıklı ve homojen veri kullanımını tesis etmek 2001-2015 dönemine ait yıllık veriler kullanılmıştır. Ele alınan zaman boyutu $(\mathrm{T}=15)$ yatay kesit boyutundan $(\mathrm{N}=28)$ küçük olduğu için Panel GMM yöntemine başvurulabilmektedir. İlgili literatürde bağımlı değişken olarak genellikle enerji arzı içerisinde yenilenebilir enerjinin oranı kullanılmaktadır. Ancak elektrik üretimi; hava şartları, ekipman kullanımı ve benzeri faktörlerden etkilendiği için doğrudan yatırımları karşılamadığı düşünülmektedir. Yatırımların sermaye stokuna yapılan net ilaveler olmasından yola çıkılarak yıllık kurulu güç kapasitesindeki artışların ele alınmasının daha uygun olduğu anlaşılmaktadır. YE teknolojileri içerisinde hidroelektrik enerjisi geleneksel ve büyük ölçekli yatırımlar olması nedeniyle yapılan çalışmalarda genellikle yer verilmemektedir. Biokütle enerjisi çoğunlukla ulaşıma yönelik teşvik edilirken jeotermal enerji coğrafi ve jeolojik koşullar nedeniyle her ülkede yeterli kapasiteye sahip değildir. Bu nedenle rüzgâr ve güneş enerjisi en çok yatırım alan YE teknoloji 
türleridir. Güneş enerjisinin maliyetlerinin son yıllarda yaşanan teknolojik gelişmelerle önemli oranlarda düşmesi, mini kurulumlarının daha yaygın olması, Türkiye'nin güneş enerji potansiyelinin yüksek olması ve Dünya'da YE yatırım trendinin güneş enerjisine evrilmesi nedeniyle çalışmada teşvik mekanizmalarının güneş enerjisi kurulu güç kapasitesine etkisi ele alınmıştır. Güneş enerjisine yönelik oluşturulan ekonometrik model eşitlik (1)'de gösterilmektedir.

$$
\begin{aligned}
& \text { GUNES }_{i, t}=\alpha_{i}+\beta_{1} \text { GUNES }_{i, t-1}+\beta_{2} \text { FITFIP }_{i, t}+\beta_{3} \text { TAX }_{i, t}+\beta_{4} \text { GSUB }_{i, t}+\beta_{5} \text { GCER }_{i, t}+ \\
& \beta_{6} \text { LOANS }_{i, t}+\beta_{7} \text { EIMP }_{i, t}+\beta_{8} \text { GDP }_{i, t}+\varepsilon_{i, t}
\end{aligned}
$$

Bağımlı değişken olarak ele alınan GUNES değişkeni güneş enerjisi kurulu güç kapasitesindeki yıllık net eklemeleri ifade etmektedir. Bağımsız değişkenler; GUNES $S_{\mathrm{i}, \mathrm{t}-1}$ değişkeni bağımlı değişkenin bir dönem gecikmesini, FITFIP değişkeni tarife/prim garantisi teşvik aracını, TAX değişkeni vergi teşviklerini, GSUB değişskeni hükümet sübvansiyonlarını, GCER değişkeni yeşil enerji sertifikasını ve LOANS değişkeni yenilenebilir enerjiye yönelik kredileri ifade etmektedir. Kukla değişkenler oluşturulurken ilgili politikaların uygulandığı yıllara 1, uygulanmadığı yıllara 0 verilerek değişkenler hazırlanmıştır. EIMP değişkeni enerji ithalatını ve GDP değişkeni gayrisafi yurtiçi hasılayı göstermektedir.

Modelde yer alan $\xi_{i, t}$ bütün zaman periyodlarında bağımsız dağılan hata terimini gösterir iken $\alpha_{i}$ katsayısı bütün ülkeler için sabit olan bağımsız dağılan birim etkiyi gösterir. Modelde kukla değişkenlerin dişında yer alan değişkenler oransal olarak hesaplanıp analize dâhil edilmiştir. Tablo 5'te ekonometrik modelde yer verilen değişkenlerin dönem aralığ́, frekansı ve kaynağı gösterilmektedir.

Tablo: 5

Ekonometrik Analizde Kullanılan Değişkenler

\begin{tabular}{|l|l|c|c|c|c|}
\hline Değişken & \multicolumn{1}{|c|}{ Açıklama } & Kategori & Dönem & Frekans & Kaynak \\
\hline GUNES & Güneş enerjisi kurulu güç kapasitesindeki yıllık net eklemeler (MW) & Bağımlı Değişken & 2001-2015 & Y1llık & IRENA \\
\hline GUNES $_{\mathrm{t}-1}$ & $\begin{array}{l}\text { Güneş enerjisi kurulu güç kapasitesindeki yıllık net eklemenin bir dönem } \\
\text { gecikmesi }\end{array}$ & $\begin{array}{c}\text { Bağımlı Değişkenin } \\
\text { Gecikmesi }\end{array}$ & $2001-2015$ & Y1llık & - \\
\hline FITFIP & Tarife Garantisi/Prim Garantisi & Kukla Değişken & $2001-2015$ & Y1llık & IEA/IRENA \\
\hline TAX & Vergiler & Kukla Değişken & $2001-2015$ & Y1llık & IEA/IRENA \\
\hline GSUB & Hükümet Sübvansiyonları & Kukla Değişken & $2001-2015$ & Y1llık & IEA/IRENA \\
\hline GCER & Yeşil sertifikalar & Kukla Değişken & $2001-2015$ & Y1llık & IEA/IRENA \\
\hline LOANS & Krediler & Kukla Değişken & $2001-2015$ & Y1llık & IEA/IRENA \\
\hline EIMP & Enerji İthalatı (Milyar \$) & Kontrol Değişken & $2001-2015$ & Y1llık & World Bank \\
\hline GDP & Gayri Safi Yurtiçi Hasıla (Milyar \$) & Kontrol Değiş̧ken & $2001-2015$ & Y1llık & World Bank \\
\hline
\end{tabular}

\subsection{Yatay Kesit Bağımlılığı Testi}

En eski yatay kesit bağımlılı̆̆ı testlerinden biri, Breusch \& Pagan (1980) tarafindan geliştirilen LM testidir. Büyük zaman boyutu ve küçük kesit boyutu $(T>N)$ söz konusu olduğunda Breusch-Pagan LM testi kullanılmaktadır. Breusch-Pagan LM testinde yer alan $\hat{\rho}_{i j}$ modelin kalıntılarından elde edilen korelasyon katsayılarını ifade etmektedir. Ancak Breusch-Pagan LM testi büyük kesit boyutlarında kullanılamamaktadır. Bunun için zaman boyutu, kesit boyutundan büyük olduğunda ve aynı zamanda kesit boyutu ile zaman boyutu arasındaki fark düşük olduğunda kullanılmak üzere alternatif bir test olarak Pesaran (2004) 
tarafından bir LM (CD $\left.\mathrm{CD}_{\mathrm{LM}}\right)$ testi ve yanı sıra kesit sayısının zaman boyutundan büyük olduğu $(N>T)$ durumlarda daha iyi sonuç veren CD (Cross-section Dependence) testi de önerilmiştir. Zaman boyutu büyük olduğunda Breusch-Pagan LM testi tercih edilmesine rağmen grup ortalaması sıfır ancak bireysel ortalama sifirdan farklı olduğunda bu test dezavantajlı olmaktadır. Pesaran vd. (2008) bu sorunu Breusch-Pagan LM test istatistiğine ortalama ve varyansı ekleyerek düzeltilmiş LM testini $\left(\mathrm{LM}_{\mathrm{adj}}\right)$ geliştirerek aşmıştır. Pesaran $\mathrm{LM}_{\text {adj }}$ testinde yer alan $\mu_{T i j}$ ortalamayı ve $v_{T i j}$ varyansı ifade etmektedir. Kesit boyutunun zaman boyutundan büyük olduğu $(N>T)$ durum hariç $(T \geq N)$ bu testin başarılı sonuç verdiği tespit edilmiştir (Birol \& Demirgil, 2020: 550-551). Yatay kesit bağımlılığı test edilirken kullanılan formüller aşağıda verilmiştir:

$$
\begin{aligned}
& \text { Breusch \& Pagan } \mathrm{LM}=T \sum_{i=1}^{N-1} \sum_{j=i+1}^{N} \hat{\rho}_{i j}^{2} \sim \chi^{2} \frac{N(N-1)}{2} \\
& \text { Pesaran } \mathrm{CD}_{\mathrm{LM}}=\sqrt{\frac{1}{N(N-1)}} \sum_{i=1}^{N-1} \sum_{j=i+1}^{N}\left(T \hat{\rho}_{i j}^{2}-1\right) \sim N(0,1) \\
& \text { Pesaran CD }=\sqrt{\frac{2 T}{N(N-1)}}\left(\sum_{i=1}^{N-1} \sum_{j=i+1}^{N} \hat{\rho}_{i j}\right) \sim N(0,1) \\
& \text { Breusch ve Pagan LM } \mathrm{LM}_{\mathrm{adj}}=\sqrt{\frac{2}{N(N-1)}} \sum_{i=1}^{N-1} \sum_{J=\dot{\mathrm{I}}+1}^{N} \frac{(T-k) \hat{\rho}_{i j}^{2}-\mu_{T i j}}{v_{T i j}} \sim N(0,1)
\end{aligned}
$$

\subsection{Pesaran Panel Birim Kök Testi}

Pesaran (2007), faktör yüklemelerini tahmin etmek yerine birimler arası korelasyonu yok etmeye dayalı bir yöntem geliştirmiştir. Önerdiği yöntem, ADF regresyonunun gecikmeli yatay kesit ortalamaları ile genişletilmiş haline dayanmakta ve bu regresyonun birinci farkı birimler arası korelasyonu ortadan kaldırmayı içeren bu yöntem, "Yatay Kesit Genelleştirilmiş Dickey Fuller (CADF)" olarak adlandırılmaktadır Basit CADF regresyon modeli ve genişletilmiş hali denklemler (6), (7), (8) aracılığıyla gösterilebilir (Tatoğlu, 2012: 223-224):

$$
\Delta Y_{i t}=\alpha_{i}+\beta_{i}^{*} Y_{i t-1}+d_{0} \bar{Y}_{t-1}+d_{1} \Delta \bar{Y}_{t}+\epsilon_{i t}
$$

Burada, $\bar{Y}_{t}$, tüm $N$ gözlemlerinin zaman t'ye göre ortalamasıdır. Gecikmeli yatay kesit ortalamaları ve birincil farklarının varlığı, bir faktör yapısı yoluyla birimler arası korelasyonu hesaba katmaktadır. Hata teriminde ya da faktörde otokorelasyon varsa, regresyon tek değişkenli durumda $Y_{i t}$ ve $\bar{Y}_{i t}$ 'nın gecikmeli birinci farklarının ilavesi ile geniş̧letilebilmektedir.

$$
\Delta Y_{i t}=\alpha_{i}+p_{i}^{*}+Y_{i t-1}+d_{0} \bar{Y}_{t-1}+\sum_{j=0}^{p} d_{j+1}+\Delta \bar{Y}_{t-j}+\sum_{k=1}^{p} 6 Y_{i, t-k}+\varepsilon_{i t}
$$

CADF regresyonu tahmin edildikten sonra, CIPS istatistiğini elde etmek için gecikmeli değişkenlerin t-istatistiklerinin ortalamaları (CADF i) alınmaktadır:

$$
\mathrm{CIPS}=\frac{1}{N}+\sum_{i=1}^{N} C A D F i
$$


CIPS istatistiğinin birleşik asimptotik limiti standart değildir ve kritik değerler çeşitli $\mathrm{T}$ ve $\mathrm{N}$ değerleri için hesaplanmıştır.

\subsection{Arellano Bond GMM Yöntemi}

Genelleştirilmiş Momentler Tahmincisi, "İki Aşamalı Araç Değişkenler Tahmincisi”" olarak da ifade edilebilmektedir. Arellano ve Bond, farkı alınmış modelin araç değişken matrisi aracılığıyla dönüştürülmesini ve dönüştürülmüş modelin genelleştirilmiş en küçük kareler tahmincisi yardımıyla tahmin edilmesi gerektiğini ileri sürmüşlerdir. Bağımlı değişkenin gecikmeli değerinden başka açıklayıcı değişkeni olmayan dinamik panel veri modeli aşağıdaki denklemler aracılığıyla ifade edilebilir (Tatoğlu, 2012: 80):

$$
Y_{i t}=\gamma Y_{i t-1}+v_{i t}(9) v_{i t}=\mu_{i}+\mu_{i t}
$$

Belirtilen modelin birinci farkının alınması aşağıdaki denklemde gösterilmektedir:

$$
Y_{i t}-Y_{i t-1}=\gamma\left(Y_{i t-1}-Y_{i t-2}\right)
$$

Birim etki modelden bu şekilde elemine edilmiştir. $\mathrm{Y}_{\mathrm{it}-1}, \mathrm{u}_{\mathrm{it}-1}$ korelasyonludur ve bu haliyle Birinci Farklar Tahmincisi aşağıya doğru sapmalıdır. Hata terimi $\left(\mathrm{u}_{\mathrm{it}}-\mathrm{u}_{\mathrm{it}-1}\right)$, MA (1) ise birim köklüdür.

$\mathrm{Bu}$ modelde, $\left(Y_{i t-1}-Y_{i t-2}\right)$ için geçerli araç değişkenler, gecikmeli değerlerdir $\left(Y_{i t-2}, Y_{i t-3}, y_{i 1}\right)$. Bu durumun nedeni, her bir gecikmeli değişkenin bir önceki fark hata terimi ile korelasyonunun sıfır olmasıdır (örneğin $\mathrm{E}\left(Y_{i t-2}\left(u_{i t}-u_{i t-1}\right)\right)=0$ ). Örneğin $\mathrm{t}=3$ için;

$$
Y_{i 3}-Y_{i 2}=\gamma\left(Y_{i 2}-Y_{i 1}\right)+\left(u_{\mathrm{i} 3}-u_{i 2}\right)
$$

$u_{i t}$ otokorelasyonsuz olduğu sürece, $\left(Y_{i 2}-Y_{i 1}\right)$ ile yüksek korelasyonlu ve $\left(u_{i 3}-\right.$ $u_{i 2}$ ) ile korelasyonsuz olan $Y_{i 1}$ uygun bir araç değişken olarak düşünülmektedir.

$$
\begin{aligned}
& \mathrm{T}=4 \text { için; } \\
& Y_{i 4}-Y_{i 3}=\gamma\left(Y_{i 3}-Y_{i 2}\right)+\left(u_{i 4}-u_{i 3}\right)
\end{aligned}
$$

$\left(Y_{i 4}-Y_{i 2}\right)$ ile yüksek korelasyonlu $\left(u_{i 4}-u_{i 3}\right)$ ile korelasyonsuz olan $Y_{i 1}$ ve $Y_{i 2}$ uygun araç değişkenler olarak düşünülmektedir.

Genel araç değişkenli birinci fark modeli matrislerle,

$$
Z \Delta Y=Z^{\prime} \Delta Y_{-1} \gamma+Z \Delta X \beta+Z^{\prime} \Delta u
$$

ya da,

$$
Z^{\prime} \Delta Y=\delta Z^{\prime} \Delta X+Z \Delta \Delta X=\left[\left(Y_{i t-1}-Y_{i t-2}\right),\left(X_{i t}-X_{i t-1}\right)\right]
$$


şeklinde gösterilebilmektedir. Genelleştirilmiş Moment (GMM) Tahmincisi ise, matrislerle aşağıdaki şekilde gösterilebilmektedir. Denklem yer alan $\widehat{\Omega}$ hata terimlerinin varyans kovaryans matrisidir.

$$
\hat{\delta}_{G M M}=\left(\Delta X^{\prime} Z\left(Z^{\prime} \hat{\Omega} Z\right)^{-1} Z^{\prime} \Delta X\right)^{-1}\left(\Delta X^{\prime} Z\left(Z^{\prime} \hat{\Omega} Z\right)^{-1} Z^{\prime} \Delta Y\right)
$$

\section{Bulgular}

Panel veri kullanılarak yapılan analizlerde, uygulamaya başlamadan önce ele alınan ülkeler arasında yatay kesit bağımlılığı olup olmadığına bakmak için birinci veya ikinci nesil birim kök testi uygulanmıştır.

Tablo: 6

\section{Yatay Kesit Bağımlılığı Test Sonuçları}

\begin{tabular}{|l|c|c|}
\hline \multicolumn{1}{|c|}{ Test Adı } & Test Değeri & Olasılık Değeri / Kritik Değer \\
\hline Pesaran CD Test & 26.512 & $\mathrm{p}=0.0000$ \\
\hline Breusch Pagan LM & 147.614 & $\mathrm{p}=0.0000$ \\
\hline
\end{tabular}

Tablo 6’da görüldüğü üzere birimler arasında yatay kesit bağımlılığg yoktur, sıfır hipotezi reddedilir. Böylelikle birinci nesil birim kök testleri yerine yatay kesit bağımlılı̆̆ını göz önünde bulunduran ikinci nesil birim kök testlerinin kullanılması uygun olacaktır. Ekonometrik modelde kukla değişkenler dişında modelde yer alan seriler Pesaran Panel Birim Kök Testine tabi tutularak durağanlıkları test edilmiştir.

Tablo: 7

\section{Birim Kök Testleri}

\begin{tabular}{|c|c|c|c|c|c|c|}
\hline \multirow{7}{*}{ ఫ्ञ } & & Değişkenler & CADF & \multirow{7}{*}{ 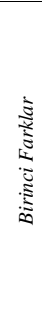 } & Değişkenler & CADF \\
\hline & \multirow{3}{*}{ Sabit } & GUNES & $\begin{array}{l}-1.762 \\
(0.462)\end{array}$ & & GUNES & $-3.235 * * *$ \\
\hline & & EIMPORT & $\begin{array}{l}-1.544 \\
(0.762)\end{array}$ & & EIMPORT & $\begin{array}{c}-3.107 \text { **** } \\
(0.003)\end{array}$ \\
\hline & & GDP & $\begin{array}{l}-2.152 \\
(0.293)\end{array}$ & & GDP & $\begin{array}{c}-3.073 * * * * \\
(0.003)\end{array}$ \\
\hline & \multirow{3}{*}{ Sabit+Trend } & GUNES & $\begin{array}{l}-1.909 \\
(0.879) \\
\end{array}$ & & GUNES & $\begin{array}{c}-3.765 * * * \\
(0.000)\end{array}$ \\
\hline & & EIMPORT & $\begin{array}{l}-2.531 \\
(0.312)\end{array}$ & & EIMPORT & $\begin{array}{c}-3.787 \text { *** } \\
(0.000)\end{array}$ \\
\hline & & GDP & $\begin{array}{l}-2.285 \\
(0.646)\end{array}$ & & GDP & $\begin{array}{c}-3.485 * * * \\
(0.000)\end{array}$ \\
\hline
\end{tabular}

Not: Tablo 7'de parantez içerisinde yer alan değerler $p$ olasılık değerlerini ifade etmektedir.

Tablo 7'ye bakıldığında analize dâhil edilen GUNES, EIMPORT ve GDP değişkenlerinin sabit ve sabit+trendli de düzey seviyede durağan olmadığı görülmektedir. İlgili değişkenlerin birinci derece farkı alındığında ise gerek sabitlide gerekse de sabitli+trendli de durağanlaştıkları Pesaran CADF (Yatay Kesit Genelleştirilmiş Dickey Fuller) birim kök testi sonucunda belirlenmiştir.

Karmaşık iktisadi ilişkileri öngörebilmek ve daha muteber sonuçlar elde edebilmek için Arellano-Bond dinamik GMM tahmincisi yöntemine başvurulmuştur. GMM tahmincisinin etkinliği açısından modelde yer verilen araç değişkenlerin doğru seçilmesi gerekir. Literatürde araç değişkenlerin doğru seçimine yönelik testler mevcuttur. En çok 
kullanılan testlerden bir tanesi Arellano ve Bond tarafından geliştirilen AR(1) ve AR(2) testleridir. AR(1) testi birinci dereceden otokorelasyon yoktur boş hipotezini sınamaktadır. Araç değişken elde edilirken kullanılan yöntem nedeniyle AR(1) testinin istatistiksel olarak ret edilmesi gerekir. Tersi bir durumda kullanılan araç değişkenin geçerli olmadığı sonucuna ulaşılır. AR(2) testi ise ikinci dereceden otokorelasyon yoktur boş hipotezini sınamaktadır. Modelde AR(2) testi istatistiksel olarak reddedilmemelidir, başka bir ifadeyle boş hipotez kabul edilmelidir. Tersi halde araç değişkenlerin doğru seçilmediği sonucu ortaya çıkar. Araç değişkenlerin doğruluğuna yönelik kullanılan bir diğer test ise Sargan Testi' dir. Sargan testte araç değişkenler geçerlidir boş hipotezini sınamaktadır. Bu boş hipotezden de anlaşılacağ1 üzere Sargan Test reddedilmemelidir (Rodman, 2006: 14). Rodman (2006) çalışmasında testlerin güvenilirlik derecesini sıralarken AR(1) ve AR(2) testlerine ilk sırayı vermektedir. Sargan testinin ise bu testlerden sonra araç değişkenlerin doğru belirlenmesinde en güvenilir test olduğu bilinmektedir. Literatürde yer alan Hansen J testinin ise kullanılan araç değişken sayısı arttıkça başarı düzeyinin azaldığı Rodman (2006)'da vurgulandığı için, çalışmanın analizinde araç değişkenlerin geçerli olduğuna yönelik boş hipotezi sınayan Hansen J testine yer verilmemiştir.

Eşitlik (1)'de gösterilen ve bağımlı değişken olan GUNES'in bir dönem gecikmesini içeren dinamik panel modeli, ilk olarak tek aşamalı dinamik GMM yöntemi ile tahmin edilmiştir. Avrupa Birliği'ne üye 27 ülke ve Türkiye için Arellano-Bond tek aşamalı dinamik GMM sonuçlarına Tablo 8'de yer verilmektedir. Sonuçlara göre Wald $\chi^{2}$ testine bakıldığında modelin bir bütün olarak \%1 anlamlılık düzeyinde istatistiksel olarak anlamlı olduğu görülmektedir. Araç değişkenlerin geçerli olup olmadığını anlamak için yapılan Sargan Test istatistiği boş hipotezi reddederek kullanılan araç değişkenlerin geçerli olmadığını göstermektedir. Ayrıca ilgili teori ile örtüşmeyecek şekilde GSUB değişkeninin negatif çıkması kullanılan araç değişkenlerin geçerli olmadığını gösteren test sonuçlarını destekler niteliktedir. Bu nedenlerle tek aşamalı dinamik GMM yöntemi uygun olmadığ 1 için iki aşamalı dinamik GMM yöntemine başvurulması dinamik model için daha uygun olacaktır. Tablo 8'in son sütunu aşamalı dinamik GMM sonuçlarını göstermektedir.

\section{Tablo: 8}

\section{Avrupa Birliği Üyesi 27 Ülke ve Türkiye için Arellano-Bond Dinamik GMM Tahmincisi Sonuçları}

\begin{tabular}{|c|c|c|}
\hline Değişkenler $\quad$ Modeller & $\begin{array}{c}\text { Tek Aşamalı } \\
\text { Dinamik GMM }\end{array}$ & $\begin{array}{c}\text { İki Aşamalı } \\
\text { Dinamik GMM }\end{array}$ \\
\hline GUNES $_{\mathrm{i}, \mathrm{t}-1}$ & $\begin{array}{c}0.5207 * * * \\
(0.0638)\end{array}$ & $\begin{array}{c}0.5547 \text { **** } \\
(0.0185)\end{array}$ \\
\hline FITFIP $_{i, t}$ & $\begin{array}{l}0.1992 * \\
(0.1143)\end{array}$ & $\begin{array}{c}0.1751 * * * \\
(0.0377)\end{array}$ \\
\hline TAX $_{i, t}$ & $\begin{array}{c}0.1614 \\
(0.1640)\end{array}$ & $\begin{array}{c}0.1074 * * \\
(0.0533)\end{array}$ \\
\hline GSUB $_{i, t}$ & $\begin{array}{l}-0.0432 \\
(0.1028) \\
\end{array}$ & $\begin{array}{c}0.0194 \\
(0.0432)\end{array}$ \\
\hline $\operatorname{GCER}_{\mathrm{i}, \mathrm{t}}$ & $\begin{array}{l}0.1389 * \\
(0.0863)\end{array}$ & $\begin{array}{c}0.0974 \text { ** } \\
(0.0396)\end{array}$ \\
\hline LOANS $_{i, t}$ & $\begin{array}{c}0.2259 \\
(0.1655)\end{array}$ & $\begin{array}{c}0.0449 \\
(0.1666)\end{array}$ \\
\hline EIMP $_{i, t}$ & $\begin{array}{c}-0.0587 * \\
(0.0337)\end{array}$ & $\begin{array}{c}-0.2205 * * \\
(0.1040)\end{array}$ \\
\hline GDP $_{i, t}$ & $\begin{array}{c}0.2015 * * \\
(0.0976)\end{array}$ & $\begin{array}{c}0.0031 * * \\
(0.0015)\end{array}$ \\
\hline
\end{tabular}


Kaya, H.İ. \& Y. Bayraktar (2021), "Kamu Teşvik Mekanizmalarının Yenilenebilir Enerji Kaynakları Üzerine Etkisi: AB Ülkeleri ve Türkiye'de Güneș Enerjisine Yönelik Dinamik Panel Veri Analizi”, Sosyoekonomi, 29(48), 181-204.

\begin{tabular}{|l|c|c|}
\hline Sabit Terim & 0.1824 & $\begin{array}{c}0.9274 * * \\
(0.4617)\end{array}$ \\
\hline Gözlem Sayısı & $(0.1433)$ & 392 \\
\hline Ülke Sayısı & 392 & 28 \\
\hline Wald $\chi^{2}$ & 28 & $4971.05 * * *$ \\
\multirow{2}{*}{ Sargan Test } & $111.46 * * * 0000]$ \\
\hline AR (1) & {$[0.0000]$} & 13.95665 \\
& $194.33994 * *$ & {$[0.9020]$} \\
\hline AR (2) & {$[0.0265]$} & -2.9947 \\
\end{tabular}

Not: () içerisindekiler standart hatalarl gösterirken, [ ] içerisindekiler p değerlerini göstermektedir.

* \%10 anlamlılık düzeyinde istatistiksel olarak anlamlıdır. ** \%5 anlamllllk düzeyinde istatistiksel olarak anlamlıdır. ${ }^{* * * \% 1}$ anlamlllık düzeyinde istatistiksel olarak anlamlıdır.

İki aşamalı GMM sonuçlarına bakıldığında Wald Testi, modelin bir bütün olarak yüzde bir anlam düzeyinde istatistiksel olarak anlamlı olduğunu göstermektedir. Araç değişkenlerin geçerliliğine yönelik AR (1) testi hata terimleri arasında birinci dereceden otokorelasyon olmadığına yönelik boş hipotezi reddetmektedir. AR (1) testinin negatif işaretli olması ve boş hipotezin reddedilmesi hesaplama yönteminden kaynaklandığı için beklenen bir durum olarak görülmektedir. AR(2) testine dikkat edildiğinde, $\mathrm{AR}(2)$ testi hata terimleri arasında ikinci dereceden otokorelasyon olmadığını boş hipotezi reddetmeyerek göstermektedir. $\mathrm{Bu}$ sonuç modelde kullanılan araç değişkenlerin doğru olduğunu göstermektedir. AR(1) ve AR(2) testlerinden sonra araç değişkenlerin geçerliliğine yönelik yapılan Sargan testi, araç değişkenlerin geçerlidir boş hipotezini ret etmeyerek modelde kullanılan araç değişkenlerin geçerli olduğunu göstermektedir.

Modelde kullanılan bağımlı değişkenin bir dönem gecikmesi olan GUNES $\mathrm{S}_{\mathrm{i}, \mathrm{t}-1}$ ile FITFIP değişkenlerinin katsayısı yüzde bir anlamlılık düzeyinde istatistiksel olarak anlamlı bulunmuştur. TAX, GCER, EIMP ve GDP değişkenlerinin katsayılarının da yüzde 5 anlamlılık düzeyinde istatistiksel olarak anlamlı olduğu görülmektedir. Buna karşılık GSUB ve LOANS değişkenlerinin ise istatistiksel olarak anlamlı olmadığı sonucuna ulaşılmıştır. İki aşamalı dinamik GMM yönteminde bağımlı değişken olan GUNES değişkeni güneş enerjisi kurulu güç kapasitesindeki yıllık net eklemeler üzerinde en fazla etkiyi gösteren değişken, bağımlı değişkenin bir dönem gecikmesi olan GUNES $_{\mathrm{i}, \mathrm{t}-1}$ değişkenidir. $\mathrm{Bu}$ değişkeni sırasıyla mutlak değer olarak EIMP, FITFIP, TAX, GCER ve GDP değişkenleri izlemektedir. GUNES $\mathrm{i}_{\mathrm{it-1}-1}$, FITFIP, TAX, GCER ve GDP ile güneş enerjisi kurulu güç kapasitesindeki yıllık net eklemeleri arasında pozitif ve anlamlı ilişki, EIMP değişkeni ise analizde yer verilen 28 ülkenin güneş enerjisi kurulu güç kapasitesindeki yıllık net eklemeler arasında negatif ve anlamlı bir ilişki bulunmaktadır.

\section{Sonuç ve Politika Önerileri}

Teşvik mekanizmalarının etkinlik düzeyinin belirlenmesi, kamu kaynakları ile finanse edilen teşvik politikaları uygulanırken optimal teşvik politikasının uygulanması açısından politika yapıcıya 1şık tutacaktır. Teşvik mekanizmalarının yenilenebilir enerji yatırımları üzerindeki etkisini inceleyen bu çalışmada, yenilenebilir enerji teşvik araçları ile güneş enerjisi kurulu güç kapasitesi arasındaki ilişki, 28 ülke için 2001-2015 dönemini 
Kaya, H.İ. \& Y. Bayraktar (2021), "Kamu Teşvik Mekanizmalarının Yenilenebilir Enerji Kaynakları Üzerine Etkisi: AB Ülkeleri ve Türkiye'de Güneş Enerjisine Yönelik Dinamik Panel Veri Analizi”, Sosyoekonomi, 29(48), 181-204.

kapsayan yıllık verilerle dinamik panel yöntemi kullanılarak analiz edilmiştir. Çalışmanın bulguları şu şekildedir:

Çalışmada güneş enerjisi kurulu güç artışının bir önceki dönem gecikmesinin etkisinin pozitif ve anlamlı olduğu ve hatta değişkenler içerisinde en fazla etkiyi gösteren bağımsız değişken olduğu sonucuna ulaşılmıştır. AB ülkelerinin yenilenebilir enerji teknolojilerine ve özel olarak güneş enerjisine yatırım yapmalarının arkasında yatan temel nedenlerden biri de enerji ithalatını azaltabilmektir. Analizde kontrol değişken olarak kullanılan EIMP değişkeninin katsayısı beklentilere uygun olarak negatif ve istatistiksel olarak anlamlı bulunmuştur.

Yenilenebilir enerji teknolojilerinin gelişme aşamasında olduğu gibi son yıllarda da AB ülkeleri ve Türkiye'de en çok tercih edilen teşvik mekanizması, tarife garantisi ve prim sistemidir. Kukla değişkenler içerisinde kullanılan tarife garantisi/prim sistemi, 2016 verilerine göre 110 ülke tarafından uygulanmaktadır. Bu araçlar vasıtasıyla hükümetler yeni yatırımcılara uzun vadeli satın alım garantisi veya üretilen miktar başına piyasa fiyatının üzerinde bir fiyat belirleyerek yatırımcının geleceğe yönelik risklerini ortadan kaldırmayı amaçlamaktadır. Çalışmada tarife garantisi/prim garantisi sistemi ile güneş enerji kurulu güç kapasite artışı arasında beklentilerle uyumlu olarak pozitif ve anlamlı bir ilişki bulunmuştur.

Yenilenebilir enerji sektörünü geliştirmek için yapılan vergi düzenlemeleri, güneş enerjisi kurulu kapasite artışını etkilemekte ve $\% 5$ düzeyinde istatistiksel olarak anlamlıdır. Li vd. (2017) AB ülkeleri üzerine yaptığı çalışmada, diğer teşvik araçlarının fotovoltaik enerjinin (güneş) gelişiminde etkisiz olduğu ancak literatürle uyumlu biçimde vergi teşviklerinin fotovoltaik enerjinin gelişmesinde etkili olduğu sonucuna ulaşmıştır. Diğer taraftan Carley (2009)'in ABD eyaletleri üzerine yaptığı çalışmanın bulguları ise vergi teşviklerinin yenilenebilir enerjide düşüşe neden olabileceği yönündedir. Bu durumun nedeni ise çok açık olmamakla birlikte, sübvansiyonların büyük üreticileri cezbetmesi, vergilerin ise $A B D$ eyaletlerinde küçük üreticilere ve hane halkına yönelik olması şeklinde ifade edilmiştir.

Çalışmada, yaygın bir kullanım alanının olması nedeniyle yeşil sertifika sisteminin beklentilerle uyumlu olarak güneş enerjisi kapasite artışında $\% 5$ istatiksel olarak anlamlı ve pozitif bir ilişki olduğu sonucuna ulaşılmıştır. YPS'nin yaygın kullanımının ABD' de olması ampirik çalışmalarında bu ülkeye yönelik olmasına neden olmuştur. Carley (2009), Yin ve Power (2010) ABD’ye yönelik çalışmalarında YPS ile yenilenebilir enerji gelişimi arasında pozitif ve anlamlı ilişki bulmuşlardır. Diğer taraftan AB ülkelerine yönelik analiz yapan Li vd. (2017) çalışmasında YPS'nin rüzgâr enerjisinde güneş enerjisine kıyasla daha etkili olduğu sonucuna ulaşmiştır.

Yenilenebilir enerji gelişimi ve GSYH arasında ilgili literatürde güçlü pozitif ilişki bulunmaktadır. Bu durumun temelinde yüksek GSYH'ye sahip ülkelerin enerji taleplerinin yüksek olması nedeniyle enerji ithalatlarının fazla olmasından dolayı enerji ithalatlarını azaltabilmek amacıyla yenilenebilir enerjiye yatırım yapmaları yatmaktadır. Diğer taraftan yenilenebilir enerji teknolojilerinin yeni teknolojiler olması, maliyetlerinin yüksek olması, 
Kaya, H.İ. \& Y. Bayraktar (2021), "Kamu Teşvik Mekanizmalarının Yenilenebilir Enerji Kaynakları Üzerine Etkisi: AB Ülkeleri ve Türkiye'de Güneş Enerjisine Yönelik Dinamik Panel Veri Analizi”, Sosyoekonomi, 29(48), 181-204.

ekipman üretiminin çeşitli gelişmiş ülkelerde toplanması gibi nedenlerden dolayı daha çok gelişmiş ülkelerde tercih edilmektedir. Beklentilere ve literatüre uygun olarak çalışmada GSYH ve güneş enerjisi kurulu kapasite artışı arasında pozitif ve anlamlı ilişki ortaya çıkmaktadır. Gelir düzeyinin artması gerek çevresel konulara bakışı değiştirmesi gerekse yenilenebilir enerji dönüşümünün getirdiği maliyetleri karşılayabilmek açısından önem kazanmaktadir.

Analizde sübvansiyonların ve kredilerin güneş enerjisi kurulu gücünü artırmadığ1 sonucuna ulaşılmıştır. Yenilenebilir enerji teşvik araçlarında kamu finansman araçları altında sınıflandırılan krediler ve sübvansiyonların beklentilerin aksine anlamlı sonuç vermediği görülmektedir. Li vd. (2017) çalışmalarında benzer bir sonuca ulaşarak kredilerin fotovoltaik enerjinin (güneş) gelişimi üzerinde etkisinin olmadığı sonucuna ulaşmıştır.

Sonuç olarak enerji arz güvenliği, çevre kaygıları, fosil yakıt kullanımının sınırları vb. unsurlar dikkate alındığında yenilebilir enerjiye yönelimin artacağı aşikardır. Yenilenebilir enerji yatırımlarının yüksek maliyetli ve geri dönüşünün uzun sürmesi gibi unsurlar dikkate alındığında teşvik mekanizmaları ile sektörün geliştirilmesi gerekmektedir. Ancak sektörün en etkin teşvik mekanizması aracılığıyla uyarılması, toplumsal maliyetlerin azalması açısından önemlidir. Çalışmada tarife garantisi/prim sistemi, vergi teşvikleri, yeşil sertifika sistemi ve GSYİH, güneş enerjisi kurulu güç kapasitesini olumlu etkilerken; sübvansiyonların ve kredilerin güneş enerjisi kurulu gücünü artırmadığı sonucuna ulaşılmıştır. Dolayısıyla bulgular 1şığında güneş enerjisi kurulu güç kapasitesini artıran teşvik mekanizmalarının geliştirilmesi; katkı yapmayan teşvik mekanizmalarının revize edilmesi suretiyle yenilenebilir enerji yatırımlarını artırmaya yönelik politikaların uygulanması gerekmektedir. Hükümetler tarafından izlenen politikaların uzun dönemli yatırım riskinin azaltılmasında oynadığı rol dikkate alındığında en etkin teşvik mekanizması aracılığıyla ilgili politikanın hayata geçirilmesi oldukça önemlidir. Ayrıca diğer yenilebilir enerji kaynakları (rüzgâr, hidroelektrik, jeotermal ve biokütle) üzerine farklı teşvik araçlarının etkinliğinin belirlenmesi, kamu kaynaklarının rasyonalize edilmesi açısından ele alınmaya değerdir. Yenilenebilir enerji yatırımlarını artırmaya yönelik teşvik mekanizmaları ve finansman yöntemleri temel alınarak yapılan pek çok çalışma bulunmaktadır. Teşvik mekanizmalarının yenilenebilir enerji yatırımlarını artırdığı konusunda genel bir kanı oluşmuştur. Diğer taraftan teşvik sistemlerini uzun yıllar kullanan ülkelerde tarife açıkları oluşabilmekte veya sistemin finansmanı tüketici üzerinden yapılarak tek taraflı mali yük oluşabilmektedir. Bu nedenle son yıllarda İspanya, Portekiz ve Almanya gibi AB ülkeleri tarife garantilerini terk etmekte veya azaltmaktadır. Bu noktada etkin olmayan teşvik mekanizmalarının tespiti ve reforme edilmesi, yeni teşvik araçlarının geliştirilmesi ve sektörün gelişimi tamamlandığında teşvik araçlarının kaldırılmasının yenilebilir enerji yatırımları üzerine etkisi gelecek çalışmalar açısından cevap aramaya değer sorulardır.

\section{Kaynaklar}

Abolhosseini, S. \& A. Heshmati (2014), "The Main Support Mechanisms to Finance Renewable Energy Development”, Renewable and Sustainable Energy Reviews, (40), 876-885. 
Kaya, H.İ. \& Y. Bayraktar (2021), "Kamu Teşvik Mekanizmalarının Yenilenebilir Enerji Kaynakları Üzerine Etkisi: AB Ülkeleri ve Türkiye'de Güneş Enerjisine Yönelik Dinamik Panel Veri Analizi”, Sosyoekonomi, 29(48), 181-204.

APEC (2012), "Renewable Energy Promotion Policies-Final Report”, APEC Project EWG 04/2011A, <https://www.apec.org/Publications/2013/01/Renewable-Energy-PromotionPolicies>, 21.08.2016.

Arellano, M. \& S. Bond (1991), "Some Tests of Specification for Panel Data: Monte Carlo Evidence and an Application to Employment Equations", The Review of Economic Studies, 58(2), 277-297.

Banja, M. \& M. Jégard \& F. Monforti-Ferrario \& J.-F. Dallemand \& N. Taylor \& V. Motola \& R. Sikkema (2017), "Renewables in the EU: An Overview of Support Schemes and Measures", EU 29100 EN, Publication Office of the European Union, <https://op.europa.eu/en/publication-detail/-/publication/83d9ab2f-647d-11e8-ab9c01aa75ed71a1/language-en>, 15.02.2020.

Birol, Y.E. \& B. Demirgil (2020), "Ekonomik Özgürlükler ve Ekonomik Büyüme İlişkisi: Brics Ülkeleri Üzerine Ampirik Bir Çalışma”, Ömer Halisdemir Üniversitesi İktisadi ve İdari Bilimler Fakültesi Dergisi, 13(3), 546-558.

Bolkesjo, T.F. \& P.T. Eltvig \& E. Nygaard (2014), “An Econometric Analysis of Support Effects on Renewable Energy Investments in Europe”, Energy Procedia, (58), 2-8.

Breusch, T.S. \& A.R. Pagan (1980), "The Lagrange Multiplier Test and Its Applications to Model Specification in Econometrics”, Review of Economic Studies, 47(1), 236-253.

Candan, A. (2004), Avrupa Birliği'nin Enerji Politikası, İKV Yayınları, İstanbul.

Carley, S. (2009), "State Renewable Energy Electricity Policies: An Empirical Evaluation of Effectiveness", Energy Policy, 37, 3071-3081.

CEER (2017), "Status Review of Renewable Support Schemes in Europe", C16-SDE-56-03, <https://www.ceer.eu/1519>, 15.05.2020.

Couture, T.D. \& K. Cory \& C. Kreycik \& E. Williams (2010), “A Policymaker’s Guide to Feed-in Tariff Policy Design”, Technical Report NREL/TP-6A2-44869, 1-144, <https://www.nrel.gov/docs/fy10osti/44849.pdf>, 15.02.2017.

Crago, C.L \& I. Chernyakhovskiy (2017), “Are Policy Incentives for Solar Power Effective? Evidence From Residential Installations in The Northeast", Journal of Environmental Economics and Management, (81), 132-151.

De Jager, D. \& C. Klessmann \& E. Stricker \& T. Winkel \& E. Visser \& M. Koper \& M. Ragwitz \& A. Held \& G. Resch \& S. Busch \& C. Panzer \& A. Gazzo \& T. Roulleau \& P. Gousseland \& M. Henriet \& A. Bouille (2011), "Financing Renewable Energy in European Energy Market", Final Report, <https://ec.europa.eu/energy/sites/ener/files/documents/2011_financing_renewable.pdf>, 15.02.2017.

EC European Commission (2013), "European Commission Guidance fort he Design of Renewable Support Schemes", Commission Staff Working Document, <https://ec.europa.eu/energy/sites/ener/files/com_2013_public_intervention_swd04_en.p df $>, 15.02 .2020$.

Eyraud, L. \& B. Clements \& A. Wane (2013), “Green Investment: Trends and Determinants", Energy Policy, (60), 852-865.

Held, A. \& M. Ragwitz \& M. Gephart \& E. Visser \& C. Klessmann (2014), "Design Features of Support Schemes for Renewable Electricity”, Project No: DESNL12116, <https://ec.europa.eu/energy/sites/ener/files/documents/2014_design_features_of_suppor t_schemes.pdf>, 15.02.2017. 
Kaya, H.İ. \& Y. Bayraktar (2021), "Kamu Teşvik Mekanizmalarının Yenilenebilir Enerji Kaynakları Üzerine Etkisi: AB Ülkeleri ve Türkiye'de Güneş Enerjisine Yönelik Dinamik Panel Veri Analizi”, Sosyoekonomi, 29(48), 181-204.

IRENA \& CEM (2015), Renewable Energy Auctions-A Guide to Design 2,

$<$ https://www.irena.org/publications/2015/Jun/Renewable-Energy-Auctions-A-Guide-toDesign>, 15.03.2017.

IRENA (2012), "Evaluating Policies in Support of The Deployment of Renewable Power", IRENA Policy Brief, <https://www.irena.org/publications/2012/Oct/Evaluating-policies-insupport-of-the-deployment-of-renewable-power>, 15.03.2016.

IRENA (N/A), Data\&Statistics, Query Tool, <https://www.irena.org/Statistics/Download-Data>, 25.01.2020.

Jacobs, D. (2009), "Framework Conditions and International Practices for Renewable Energy Support Mechanisms", <https://www.osce.org/files/f/documents/0/b/41339.pdf>, 13.10.2016.

Jenner, S. \& F. Groba \& J. Indvik (2013), “Assessing the Strength and Effectiveness of Renewable Electricity Feed-in Tariffs in European Union Countries”, Energy Policy, (52), 385-401.

Johnstone, N. \& I. Hascic \& D. Popp (2010), "Renewable Energy Policies and Technological Innovation: Evidence Based on Patent Counts", Environ Reseource Economics, (45), $133-155$.

Kaya, H.İ. (2017), “Teşvik Mekanizmalarının Yenilenebilir Enerji Yatırımları Üzerine Etkisi: AB Ülkeleri ve Türkiye'de Güneş Enerjisi Yatırımlarına Yönelik Ampirik Bir Çalışma”, İstanbul Üniversitesi Sosyal Bilimler Enstitüsü, Yayımlanmamış Doktora Tezi, İ̀stanbul.

Kilinc-Ata, N. (2016), "The Evaluation of Renewable Energy Policies Across EU Countries and US States: An Econometric Approach", Energy for Sustainable Development, (31), 83-90.

Kitzing, L. \& C. Mitchell \& P.E. Morthorst (2012), "Renewable Energy Policies in Europe: Converging or Diverging?", Energy Policy, (51), 192-201.

Li, S.J. \& T.H. Chang \& S. Chang (2017), "The Policy Effectiveness of Economic Instruments for the Photovoltaic and Wind Power Development in the European Union", Renewable Energy, (101), 660-666.

Marques, A.C. \& J.A. Fuinhas \& J.R. Manso (2010), "Motivations driving renewable energy in European Countries: A Panel Data Approach”, Energy Policy, (38), 6877-6885.

Marques, A.C. \& J.A. Fuinhas (2011), "Drivers Promoting Renewable Energy: A Dynamic Panel Approach", Renewable and Sustainable Energy Reviews, (15), 1601-1608.

Mendonça, M. (2007), Feed-in Tariffs: Accelerating the Deployment of Renewable Energy, London: EarthScan.

Nicolini, M. \& M. Tavoni (2017), “Are Renewable Energy Subsidies Effective? Evidence from Europe", Renewable and Sustainable Energy Reviews, (74), 412-423.

Pesaran, M. \& A.H. Ullah \& T. Yamagata (2008), “A Bias-Adjusted LM Test of Error Cross-Section Independence", Econometrics Journal, 11(1), 105-127.

Pesaran, M.H. (2004), "General Diagnostic Tests for Cross Section Dependence in Panels", Cambridge Working Papers in Economics No. 0435, University of Cambridge.

Polzin, F. \& M. Migendt \& F.A. Taube \& P. Flotow (2015), "Public Policy Influence on Renewable Energy Investment-A Panel Data Study Across OECD Countries”, Energy Policy, (80), 98-111.

REEEP/UNIDO (2013), "Financing Options for Renewable Energy and Energy Efficiency-Module 19", içinde: Sustainable Energy Regulation and Policymaking for Africa, <http://africatoolkit.reeep.org/>, 05.03.2017. 
REN21 (2016), Renewables 2016 Global Status Report, <https://www.ren21.net/wpcontent/uploads/2019/05/REN21_GSR2016_FullReport_en_11.pdf>, 15.06.2017.

Romano, A. \& G.A. Scandurra \& A. Carfora \& M. Fodor (2017), "Renewable Investments: The Impact of Green Policies in Developing and Developed Countries", Renewable and Sustainable Energy Reviews, (68), 738-747.

Roodman, D. (2006), "How to do xtabond2: An Introduction to 'Difference' and 'System' GMM in Stata", The Center for Global Development Working Paper Series No: 103. <https://papers.ssrn.com/sol3/papers.cfm?abstract_id=982943>, 15.05.2016.

Schallenberg-Rodriguez, J. (2017), "Renewable Electricity Support Systems: Are Feed-in Systems Taking The Lead?", Renewable and Sustainable Energy Reviews, (76), 1422-1439.

Smith, M.G. \& J. Urpelainen (2014), “The Effect of Feed-in Tariffs on Renewable Electricity Generation: An Instrumental Variables Approach", Environmental Resource Economics, (57), 367-392.

Tatoğlu, F. (2012), İleri Panel Veri Analizi-Stata Uygulamalı, Beta Yayınları, İstanbul.

Turkenburg, W.C. \& D.J. Arent \& R. Bertani \& A. Faaij \& M. Hand \& W. Krewitt \& E.D. Larson \& J. Lund \& M. Mehos \& T. Merrigan \& C. Mitchell \& J.R. Moreira \& W. Sinke \& V. Sonntag-O'Brien \& B. Thresher \& W. van Sark \& E. Usher \& E. Usher (2012), "Chapter 11 - Renewable Energy", içinde: Global Energy Assessment - Toward a Sustainable Future, Cambridge University Press, Cambridge, UK and New York, NY, USA and the International Institute for Applied Systems Analysis, Laxenburg, Austria, 761-900.

Yin, H. \& N. Powers (2010), "Do State Renewable Portfolio Standards Promote in-state Renewable Generation”, Energy Policy, (38), 1140-1149.

Zhao, Y. \& K. Tang \& L. Wang (2013), "Do Renewable Electricity Policies Promote Renewable Electricity Generation? Evidence from Panel Data", Energy Policy, (62), 887-897. 